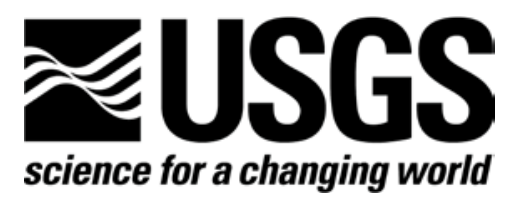

\title{
Trace-Element Analyses of Core Samples from the 1967-1988 Drillings of Kilauea Iki Lava Lake, Hawaii
}

By Rosalind Tuthill Helz

Open-File Report 2012-1050

U.S. Department of the Interior

U.S. Geological Survey 


\section{U.S. Department of the Interior \\ KEN SALAZAR, Secretary}

\section{U.S. Geological Survey \\ Marcia K. McNutt, Director}

U.S. Geological Survey, Reston, Virginia: 2012

For more information on the USGS-the Federal source for science about the Earth, its natural and living resources, natural hazards, and the environment-visit http://www.usgs.gov or call 1-888-ASK-USGS

For an overview of USGS information products, including maps, imagery, and publications, visit $h$ ttp://www.usgs.gov/pubprod

To order this and other USGS information products, visit http://store.usgs.gov

Suggested citation:

Helz, R.T., 2012, Trace-element analyses of core samples from the 1967-1988 drillings of Kilauea Iki lava lake, Hawaii: U.S. Geological Survey Open-File Report 2012-1050, 46 p., available only at $h$ ttp://pubs.usgs.gov/of/2012/1050.

Any use of trade, product, or firm names is for descriptive purposes only and does not imply endorsement by the U.S. Government.

Although this report is in the public domain, permission must be secured from the individual copyright owners to reproduce any copyrighted material contained within this report. 


\section{Contents}

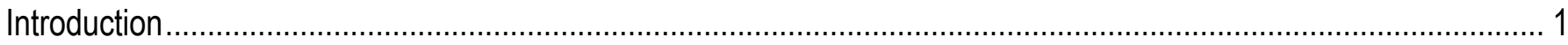

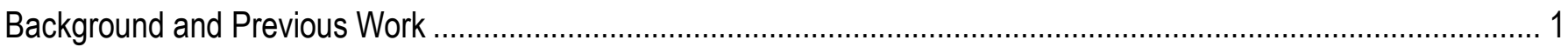

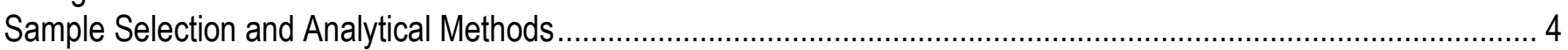

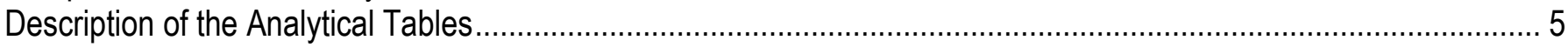

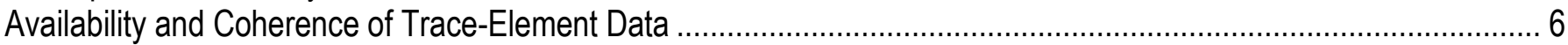

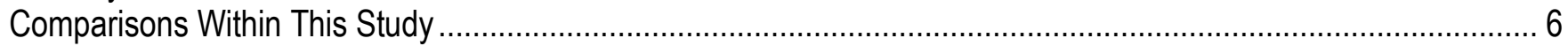

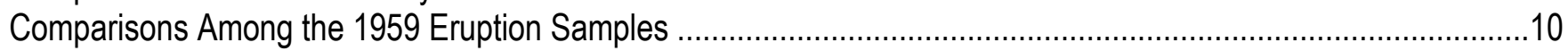

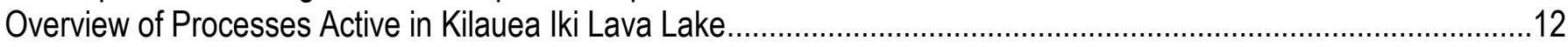

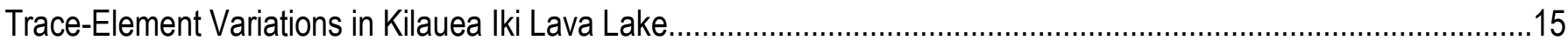

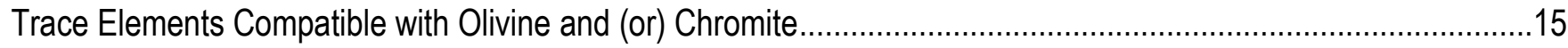

Trace Elements Compatible with Pyroxene and (or) Plagioclase ...................................................................17

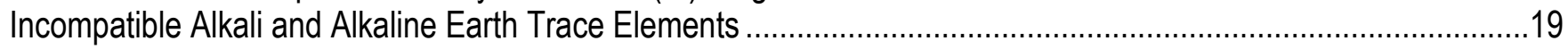

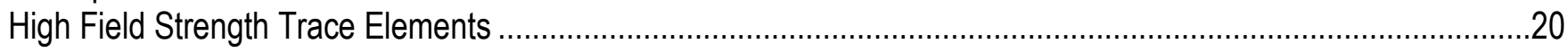

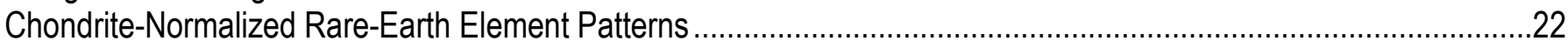

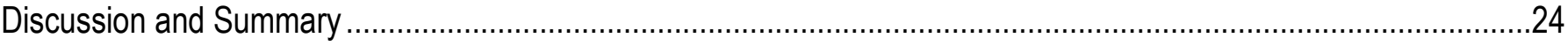

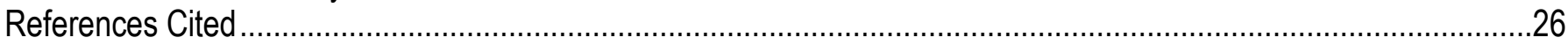

\section{Figures}

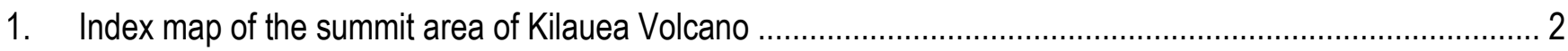

2. Plan view of the post-1959 surface of Kilauea Iki ................................................................................. 2

3. Cross section of Kilauea Iki lava lake taken along the central line of closely spaced levelling stations shown in figure 2

4. $\mathrm{MgO}$ content (weight percent) of olivine-phyric core versus depth below the surface of Kilauea Iki lava

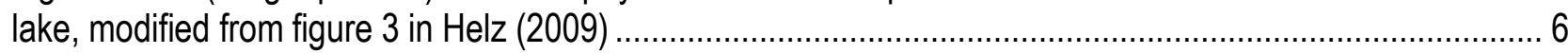

5. Plots comparing instrumental neutron-activation analysis and energy-dispersive X-ray fluorescence data for five elements from the present study ......................................................................................... 8

6. $\mathrm{Cr}_{2} \mathrm{O}_{3}$ values (weight percent) plotted against instrumental neutron-activation analysis determinations for $\mathrm{Cr}$ in parts per million for all samples in the present study.

7. Concentrations of nine elements, in parts per million, plotted against $\mathrm{MgO}$ content, in weight percent, for samples from the 1959 eruption ...

8. $\mathrm{Cr}, \mathrm{Ni}, \mathrm{Zn}$, and $\mathrm{Cu}$ concentrations, in parts per million, versus $\mathrm{MgO}$ content, in weight percent, for drill core plus samples from the 1959 eruption, as indicated in the key within each plot.....

9. Sc, Sr, and $\mathrm{Y}$ concentrations, in parts per million, versus $\mathrm{MgO}$ content, in weight percent, for drill core samples plus samples from the 1959 eruption, as indicated in the key within each plot..

10. $\mathrm{Rb}, \mathrm{Ba}$, and $\mathrm{Cs}$ concentrations, in parts per million, versus $\mathrm{MgO}$ content, in weight percent, for drill core samples plus samples from the 1959 eruption, as indicated by the key within each plot.

11. Trace elements, in parts per million, versus $\mathrm{MgO}$ contents, in weight percent, for drill core plus samples from the 1959 eruption, as indicated in the key within each plot.....

12. Chondrite-normalized rare-earth element patterns for samples from the 1959 eruption plus shallow sample 67-3-6.8 
13. Chondrite-normalized rare-earth element patterns for segregation veins and glasses, differentiated oozes from KI79-1R and small late veins and oozes together with four strongly depleted samples from zones VI and VII.

14. Enrichment factors for the three most differentiated samples from Kilauea Iki lava lake, compared with the average of four undifferentiated samples with $\mathrm{MgO}=16.05$ to 18.84 weight percent......

\section{Tables}

1. Elements analyzed, by method or by study.

2. Differentiation processes in Kilauea Iki lava lake, modified from Helz (1987a, 2009).....

3. Major-element compositions of extreme differentiates from Kilauea Iki for which trace-element data have been obtained.

4. Average olivine compositions in selected samples from Kilauea lki lava lake.

A1. Instrumental neutron-activation analyses of trace elements for samples from the 1959 Kilauea Iki eruption.

A2. Instrumental neutron-activation analyses of trace elements for samples from the 1967 Kilauea Iki drill core.

A3. Instrumental neutron-activation analyses of trace elements for samples from the 1975 Kilauea Iki drill core.

A4. Instrumental neutron-activation analyses of trace elements for samples from the 1979 Kilauea Iki drill core.

A5. Instrumental neutron-activation analyses of trace elements from the 1981 Kilauea lki drill core.

A6. Instrumental neutron-activation analyses of trace elements from the 1988 Kilauea lki drill core.

B1. Energy-dispersive X-ray fluorescence analyses of trace elements in samples from the 1959 Kilauea Iki eruption.

B2. Energy-dispersive X-ray fluorescence analyses of trace elements for samples from 1967 Kilauea Iki drill core.

B3. Energy-dispersive X-ray fluorescence analyses of trace elements for samples from 1975 Kilauea Iki drill core.

B4. Energy-dispersive X-ray fluorescence analyses of trace elements for samples from 1979 Kilauea lki core.

B5. Energy-dispersive X-ray fluorescence analyses of trace elements from 1981 Kilauea Iki drill core.

\section{Conversion Factors}

Inch/Pound to SI

\begin{tabular}{llll}
\hline & Multiply & By & To obtain \\
\hline foot $(\mathrm{ft})$ & & 0.3048 & meter $(\mathrm{m})$
\end{tabular}

SI to Inch/Pound

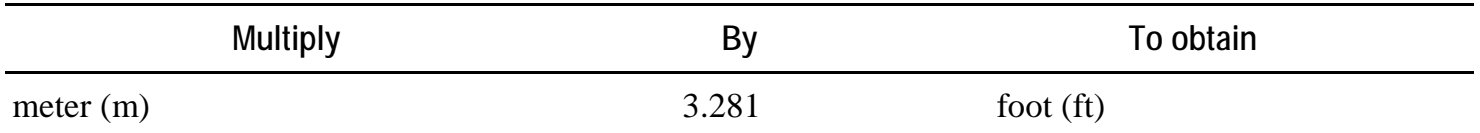

Temperature in degrees Celsius $\left({ }^{\circ} \mathrm{C}\right)$ may be converted to degrees Fahrenheit $\left({ }^{\circ} \mathrm{F}\right)$ as follows: ${ }^{\circ} \mathrm{F}=\left(1.8 \mathrm{x}^{\circ} \mathrm{C}\right)+32$ 


\title{
Trace-Element Analyses of Core Samples from the 1967-1988 Drillings of Kilauea Iki Lava Lake, Hawaii
}

\author{
By Rosalind Tuthill Helz
}

\section{Introduction}

This report presents previously unpublished analyses of trace elements in drill core samples from Kilauea Iki lava lake and from the 1959 eruption that fed the lava lake. The two types of data presented were obtained by instrumental neutron-activation analysis (INAA) and energy-dispersive X-ray fluorescence analysis (EDXRF). The analyses were performed in U.S. Geological Survey (USGS) laboratories from 1989 to 1994. This report contains 93 INAA analyses on 84 samples and 68 EDXRF analyses on 68 samples. The purpose of the study was to document trace-element variation during chemical differentiation, especially during the closed-system differentiation of Kilauea Iki lava lake.

\section{Background and Previous Work}

Kilauea Iki lava lake formed during the 1959 eruption of Kilauea Volcano, when lava ponded in the previously existing Kilauea Iki pit crater (located just east of the summit caldera, see fig. 1). The eruption was well documented and extensively sampled, and 23 samples of 1959 eruption material were analyzed by Murata and Richter (1966). Wright (1973) and Helz (1987a) have demonstrated and quantified the role of magma mixing during this eruption, using the bulk chemical data of Murata and Richter (1966), plus mineral and glass chemistry obtained using the electron microprobe.

Kilauea Iki lava lake remained accessible throughout the period of its cooling and crystallization (from 1959 to the mid-1990s) and therefore has been drilled repeatedly; the earliest core, recovered in 1960-1962, was described by Richter and Moore (1966). Subsequent drilling was carried out in 1967, 1975, 1976, 1979, 1981, and 1988. The locations of the resulting drill holes are shown in plan view in figure 2 and in cross section in figure 3. Further details on the later drilling episodes, plus petrographic logs of the cores, are given in Helz and others (1984) for the 1967-1979 cores, in Helz and Wright (1983) for the 1981 cores, and in Helz (1993) for the 1988 cores. 

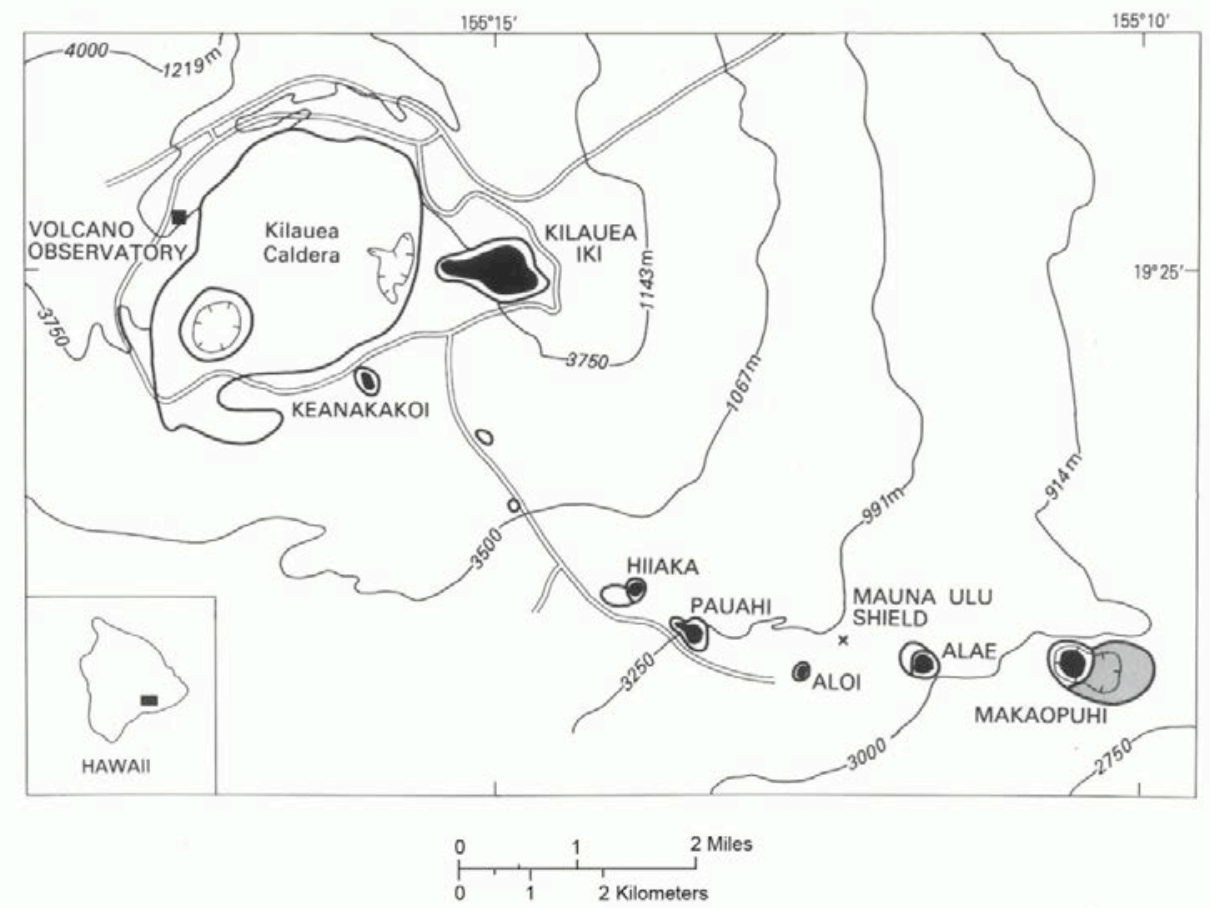

Contour Interval 250 Feet $=76$ Meters

Figure 1. Index map of the summit area of Kilauea Volcano. All historical lava lakes formed to date (1994) are shown in black. The prehistoric Makaopuhi lava lake is shown in the gray, stippled pattern. The historical lava lakes in Aloi, Alae, and Makaopuhi pit craters are now covered by lavas from the Mauna Ulu satellite shield, the summit of which is indicated by the " $X$ ".

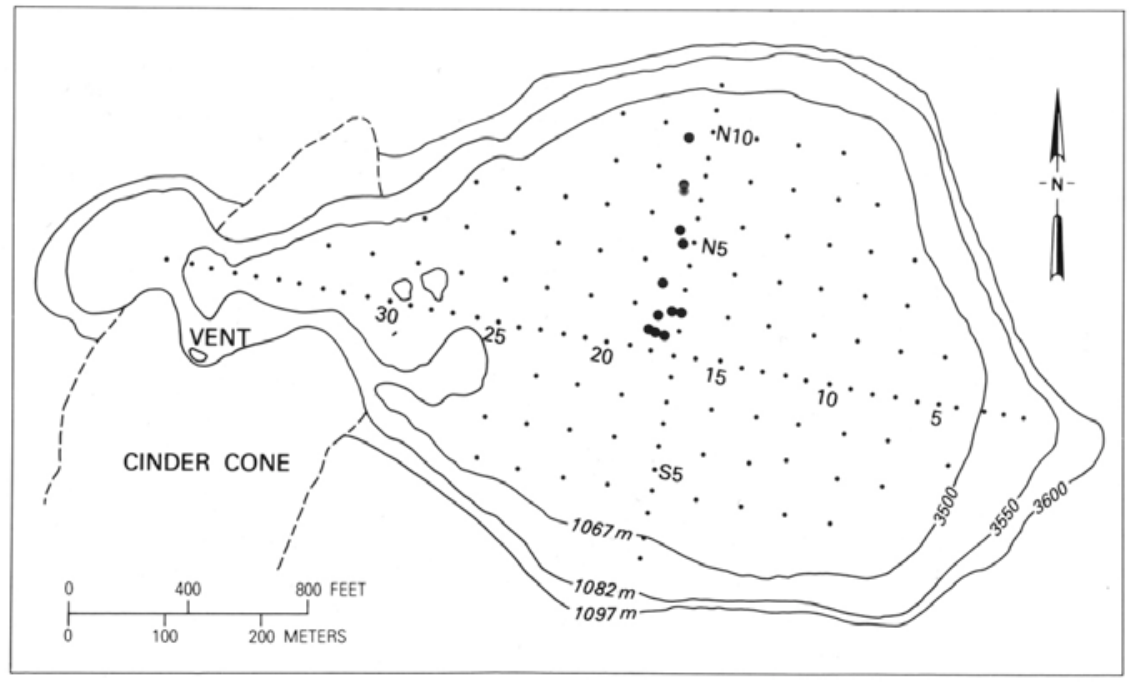

Figure 2. Plan view of the post-1959 surface of Kilauea lki. The lake surface has a network of leveling stations, the locations of which are shown by the small dots. Larger dots indicate the locations of holes drilled from 1967 to 1988. 


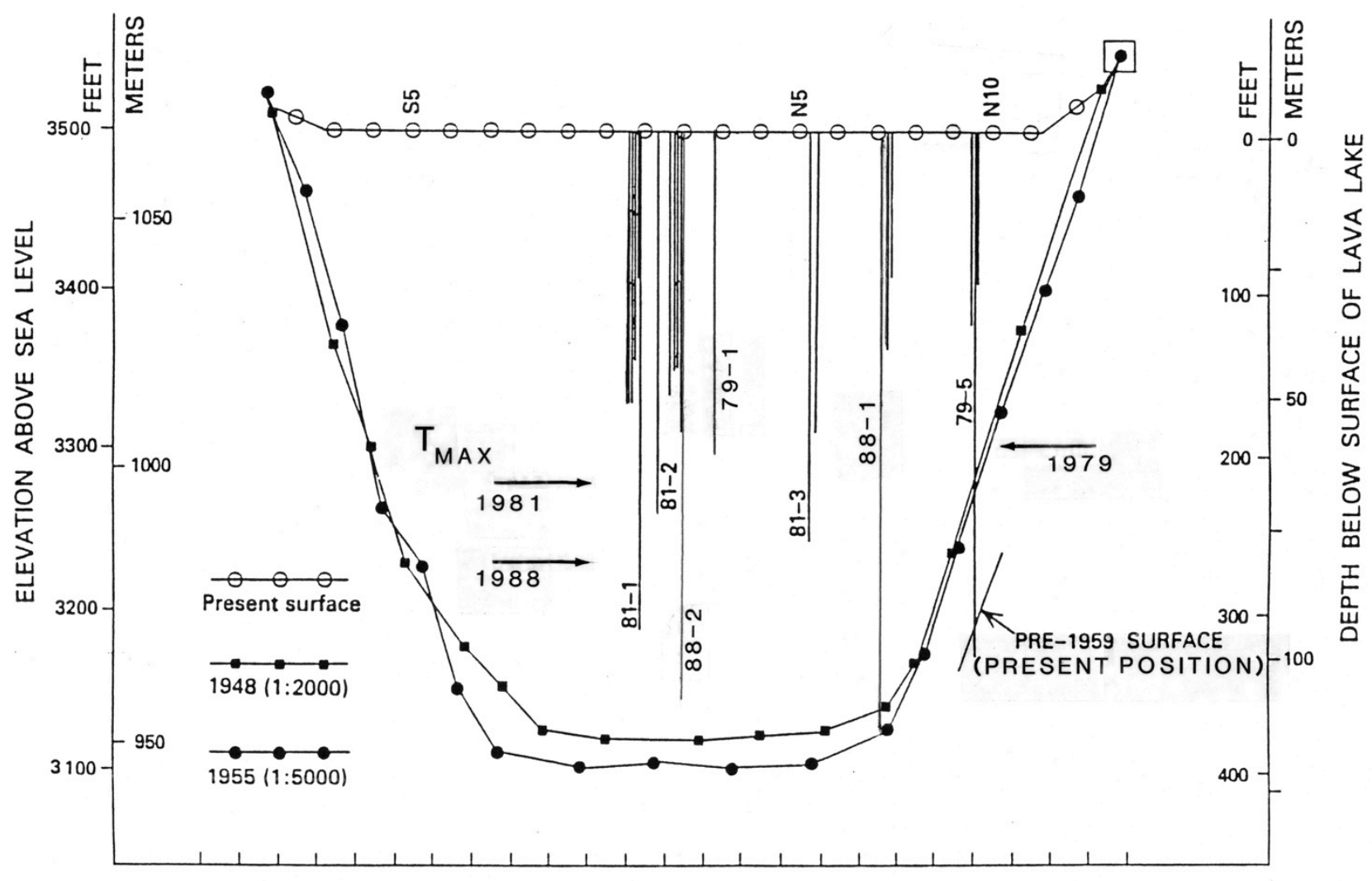

Figure 3. Cross section of Kilauea Iki lava lake taken along the central line of closely spaced levelling stations shown in figure 2. The present surface of the lava lake and two pre-eruption profiles are shown; they are joined at the square (upper right). The two pre-eruption profiles are taken from two different topographic maps: one (at $1: 2,000$ ) is based on aerial photographs taken in 1948; the other (at 1:5,000) is based on aerial photographs taken in 1955. Both maps were prepared by R. Jordan, U.S. Geological Survey, Flagstaff, Arizona. The present position of the lake bottom has been intersected only at the location of drill hole KI79-5 and lies 20 to 23 meters deeper here and across the flat central floor than the pre-eruptive topography would suggest. Vertical exaggeration is 4:1.

The drill holes are shown as vertical lines projected onto this cross section. Several of the drill hole locations have been reoccupied more than once, in order to sample the same section of the crust in several stages of development. Spacing between these closely spaced holes is not to scale in this figure. Only the deepest hole in each cluster has been labeled, for clarity. The arrows mark the position of the thermal maximum in 1979, 1981, and 1988 , as determined by analyzing glass in quenched, partially molten drill core using the glass geothermometer of Helz and Thornber (1987). 
Kilauea Iki cores have been studied extensively, including petrography and microprobe analysis of individual phases, plus chemical analysis of bulk samples. The results of studies based on the 19671981 cores were reported in Helz (1980; 1987a, b), Helz and Thornber (1987), Helz and others (1989), Helz and others (1994), and Barth and others (1994). Helz (2009) was the first paper to make use of the major-element analytical results for the 1988 core, which were presented in Helz and Taggart (2010).

There have been few prior reports on the trace-element compositions of core from the lava lake, with the notable exception of a study by Pitcher and others (2009) of the platinum-group elements and Re in a suite of 14 samples from Kilauea Iki plus 5 from the 1959 eruption. The 1959 eruption pumices, by contrast, have been analyzed for various trace elements twice previously, by Gunn (1971) and by Tilling and others (1987). The results reported here will be compared with those of the earlier studies.

\section{Sample Selection and Analytical Methods}

After 242 Kilauea Iki samples had been analyzed for major elements (Helz and others, 1994; Helz and Taggart, 2010), the present subset of 84 was submitted for trace-element analysis. Samples for trace-element analysis were chosen to represent all rock types found in the lake and the full range of major-element compositional variation observed. In order to obtain data for a large suite of trace elements of varying geochemical behavior, the samples were submitted for both INAA and EDXRF analysis.

The INAA analyses were obtained between 1989 and 1994; the samples were irradiated at the USGS TRIGA reactor in Denver, Colorado, and analyzed in the USGS Radiochemistry Laboratory in Reston, Virginia. The general INAA procedure is described in Baedecker and McKown (1987), and the data reduction techniques are given in Grossman and Baedecker (1987) and Baedecker and Grossman (1989). Eighty-five samples were analyzed over the period from 1989 to 1994. This procedure generates values for a number of elements found in the major-element analyses, as well as approximately 27 trace elements. Of the elements normally reported as majors ( $\mathrm{Na}, \mathrm{K}, \mathrm{Ca}, \mathrm{Ti}, \mathrm{Cr}$, and $\mathrm{Fe}$ ), only the values for $\mathrm{Cr}$ have been included in the tables in this report. All data were generated by the standard methods as described except for the Cs values for job CE96, which were recounted 525 days after irradiation in order to obtain better values. The analysts were J.N. Grossman and P.A. Baedecker.

The EDXRF analyses were performed in 1992 in the USGS analytical laboratory in Menlo Park, California. The EDXRF procedure is that of Johnson and King (1987). Elements requested included Ni,

$\mathrm{Cu}$, and $\mathrm{Zn}$, which were fluoresced with a germanium target, and $\mathrm{Rb}, \mathrm{Sr}, \mathrm{Y}, \mathrm{Zr}$, and $\mathrm{Nb}$, fluoresced with a silver target. Ba, La, and Ce analyses, which would have required a different target, were not requested. The analyst was J. Kent.

In order to evaluate the observed variation of $\mathrm{Zn}$ in the lava lake samples, it was necessary to obtain some data for $\mathrm{Zn}$ in olivines. These data were obtained on the JEOL electron microprobe (Reston, Va.). The usual olivine standardization package (including $\mathrm{Si}, \mathrm{Fe}, \mathrm{Mg}, \mathrm{Ca}, \mathrm{Mn}, \mathrm{Ni}, \mathrm{Al}$, Ti, and $\mathrm{Cr}$ ) was expanded to include Zn. Counting times used for Zn were 180 seconds (on peak) and 90 seconds both above and below the peak (for background), in order to obtain reasonably stable counts. The modified package was set up by Harvey Belkin (USGS), whose assistance is greatly appreciated. 


\section{Description of the Analytical Tables}

Tables of analytical data are presented at the end of this report. Table A1 presents INAA data for the 1959 eruption samples, while tables A2-A6 present INAA data for the 1967, 1975, 1979, 1981, and 1988 core samples. Table B1 includes the EDXRF data for the 1959 eruption samples, and tables B2-5 include the results for the 1967, 1975, 1979, and 1981 samples. No EDXRF analyses were obtained for the 1988 core samples.

Each sample is identified by a field number. For the 1959 samples (in tables A1 and B1), these are of the form "Iki-1" and correspond to numbers given by scientists observing the 1959 eruption. Entries under "Lab no." of the form "S-1" correspond to designations given in table 1 of Murata and Richter (1966). The analysis of Iki-3 was presented in Helz and Taggart (2010), and the lab number is the one for the major-element analysis.

For the samples from the lava lake (tables A2-A6 and B2-B5), the field number is of the form “67-1-89.0," where the first number gives the year the sample was drilled (1967), the second is the number of the drill hole within the year (1), and the third is the depth from which the sample was recovered (in this case 89.0 feet). For these samples, the "Lab. no." is a number assigned for purposes of sample control within the USGS analytical laboratory system. In all cases, this number corresponds to the number for the major-element analysis, as given in Helz and others (1994) or Helz and Taggart (2010). These are usually not the same as individual lab numbers in the trace-element analytical jobs. The next line shows the job numbers for the trace elements. The INAA data include job numbers CD53, CE76, CE92, CG74, CJ12, and CJ13. The EDXRF data are from jobs CH90 and CH91.

Concentration data for trace elements are reported as given in the internal reports. The INAA reports included the 1-sigma analytical uncertainty from counting statistics, but those numbers are not repeated here. Estimates of precision are given in Baedecker and McKown (1987). All concentrations are in parts per million except for Au, which is given in parts per billion. Entries shown as “ $<$ ” indicate concentrations below the limit of detection, while "nd" means that the element was not determined for that sample in the particular analytical job.

In all cases, the tables include the bulk MgO content of the samples, as reported in Murata and Richter (1966), Helz and others (1994) and Helz and Taggart (2010). Additional information on each sample is provided below the analyses. For the 1959 eruption samples, tables A1 and B1 also give the phase of the eruption, the fraction of juvenile magma present in the sample (Wright, 1973) and the quenching temperature of the glass present in the sample (Helz, 1987a). For samples from the lava lake (tables A2-A6 and B2-B5), the first of the lower entries repeats descriptions of the samples as given in Helz and others (1994) and Helz and Taggart (2010). The Roman numerals give the zone numbers where defined [Helz and others (1989); Helz and Taggart (2010)]. The zonation pattern is shown in figure 4.

The tables also note whether the sample analyzed contains glass (= quenched melt) or not. Lastly, the core has been put into one of three categories, depending on its pre-quenching temperature. "High" samples are those quenched from temperatures above the solidus, which lies at 970 to $980^{\circ} \mathrm{C}$; these contain glass interpreted as having been a stable melt phase prior to quenching. "Medium" samples are those quenched from temperatures below the solidus but above the boiling point of water (approximately $110^{\circ} \mathrm{C}$ for the geothermal system in the lake, as the water contains some dissolved salts). "Low" temperature samples are those that were quenched from $110^{\circ} \mathrm{C}$ and hence had been in contact with liquid water (which contained some dissolved salts, mainly $\mathrm{Na}_{2} \mathrm{SO}_{4}$ ) prior to drilling. This information is included because it bears on the freshness of the material analyzed, though all Kilauea Iki core is pristine by normal geologic standards. 


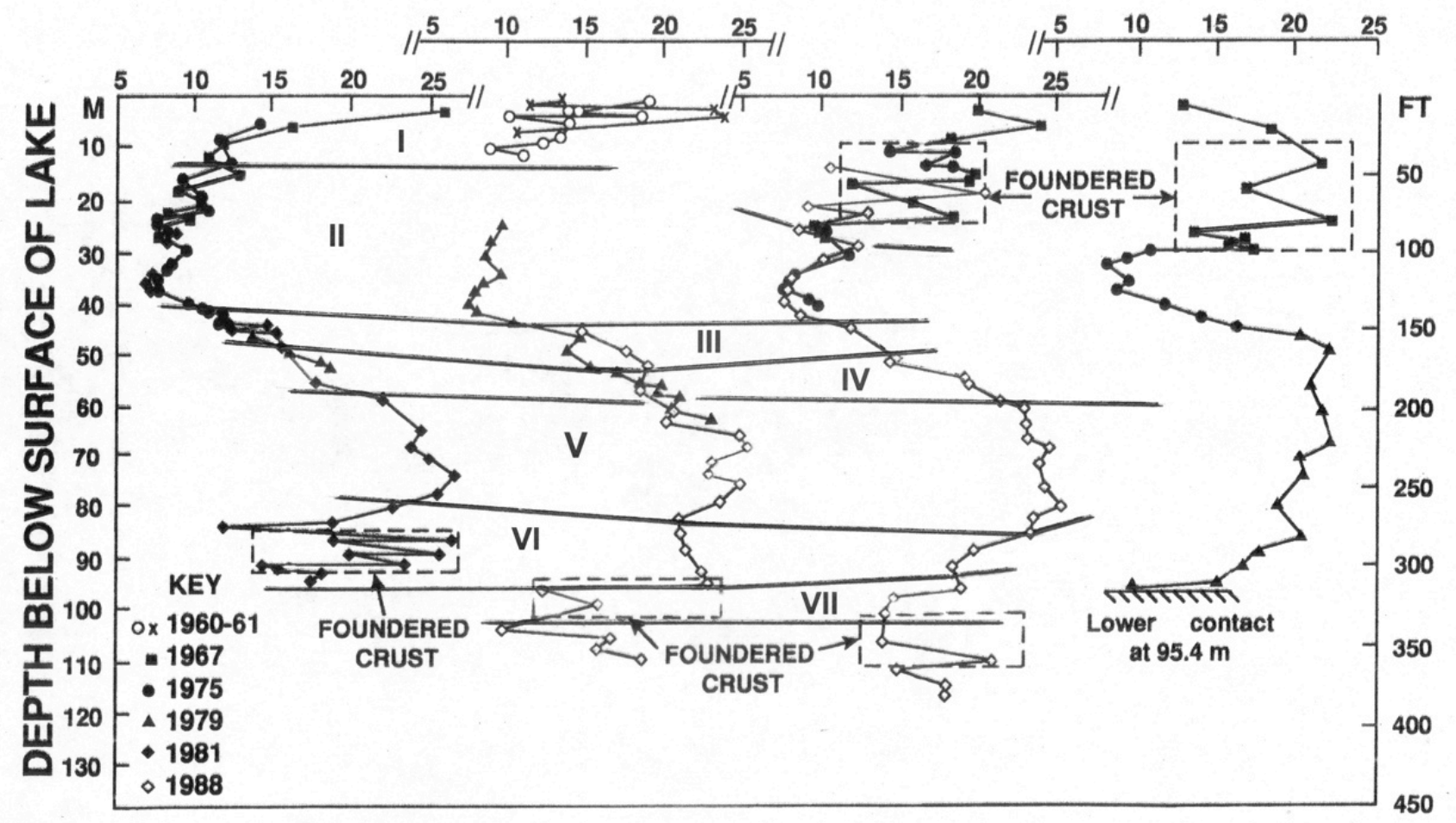

Figure 4. $\mathrm{MgO}$ content (weight percent) of olivine-phyric core versus depth below the surface of Kilauea lki lava lake, modified from figure 3 in Helz (2009). Zone boundaries, as defined by the results of Helz and others (1994) and Helz and Taggart (2010), are shown and the enclosed areas labeled.

\section{Availability and Coherence of Trace-Element Data}

This section reviews the coherence of the trace-element data, first within the new data presented here and then among the three sets of analyses available for the 1959 eruption samples (this study; Gunn, 1971; and Tilling and others, 1987). Table 1 summarizes the availability of data and methods used in these various studies and shows that two to four kinds of data are available for 16 of the 23 elements. Elements listed in only one column are As, Se, Sb, Ta, Au, and Th (INAA only) and Nb (EDXRF only); of these only $\mathrm{Nb}$, Ta, and Th are consistently above the limit of detection in these samples.

\section{Comparisons Within This Study}

Five elements (Ni, Zn, Rb, Sr, and $\mathrm{Zr}$ ) are reported in both the INAA and EDXRF tables. In addition, there are two sets of $\mathrm{Cr}$ data, the INAA data reported here and the values reported with the major-element analyses (Helz and others, 1994; Helz and Taggart, 2010) or, for the 1959 eruption samples, in Wright (1973). These data are compared in figures 5 and 6 below. 
Table 1. Elements analyzed, by method or by study.

[INAA, instrumental neutron-activation analysis; EDXRF, energy-dispersive X-ray fluorescence analysis; " $X$ " indicates element concentrations in agreement with at least one other set of analytical data; " $\mathrm{x}$ " indicates inconsistent results or only one data set]

\begin{tabular}{|c|c|c|c|c|c|}
\hline Element & $\begin{array}{l}\text { This study } \\
\text { INAA }\end{array}$ & $\begin{array}{c}\text { This study } \\
\text { EDXRF }\end{array}$ & $\begin{array}{c}\text { Tilling and } \\
\text { others (1987) } \\
\text { INAA }\end{array}$ & $\begin{array}{c}\text { Tilling and } \\
\text { others (1987) } \\
\text { other* }\end{array}$ & $\begin{array}{c}\text { Gunn (1971) } \\
\text { XRF }\end{array}$ \\
\hline Sc & $\mathrm{X}$ & & $\mathrm{X}$ & & \\
\hline $\mathrm{Cr}$ & $\mathrm{X}$ & & $\mathrm{X}$ & & $\mathrm{X}$ \\
\hline Co & $\mathrm{X}$ & & $\mathrm{X}$ & & x-high \\
\hline $\mathrm{Ni}$ & $\mathrm{X}$ & $\mathrm{X}$ & & x-low & $\mathrm{X}$ \\
\hline $\mathrm{Zn}$ & x-low & $\mathrm{X}$ & & x-high & $\mathrm{X}$ \\
\hline $\mathrm{Cu}$ & & $\mathrm{x}$ & & & $\mathrm{x}$ \\
\hline As & $\mathrm{x}$ & & & & \\
\hline Se & $\mathrm{X}$ & & & & \\
\hline $\mathrm{Rb}$ & $\mathrm{X}$ & $\mathrm{X}$ & & & x-low \\
\hline $\mathrm{Sr}$ & x-some high & $\mathrm{X}$ & X-some low & & $\mathrm{X}$ \\
\hline $\mathrm{Y}$ & & $\mathrm{x}$ & & $\mathrm{X}$ & $\mathrm{X}$ \\
\hline $\mathrm{Zr}$ & $\mathrm{x}$ & $\mathrm{x}$ & & & \\
\hline Mo & $\mathrm{x}$ & & & $\mathrm{X}$ & \\
\hline $\mathrm{Sb}$ & $\mathrm{x}$ & & & & \\
\hline Cs & $\mathrm{x}$ & & $\mathrm{x}$ & & \\
\hline $\mathrm{Ba}$ & $\mathrm{X}$ & & $\mathrm{X}$ & & $\mathrm{X}$ \\
\hline REE & X (8) & & X (8) & & \\
\hline Hf & $\mathrm{X}$ & & $\mathrm{X}$ & & \\
\hline $\mathrm{Nb}$ & & $\mathrm{x}$ & & & \\
\hline $\mathrm{Ta}$ & $\mathrm{x}$ & & & & \\
\hline $\mathrm{Au}$ & $\mathrm{x}$ & & & & \\
\hline Th & $\mathrm{X}$ & & & & \\
\hline $\mathrm{U}$ & $\mathrm{X}$ & & & $\mathrm{X}$ & \\
\hline Other & & & & $\mathrm{V}, \mathrm{Ga}, \mathrm{Pb}$ & $\mathrm{Ga}$ \\
\hline
\end{tabular}

*Emission spectroscopy except for U, which was done by fission track counting. 

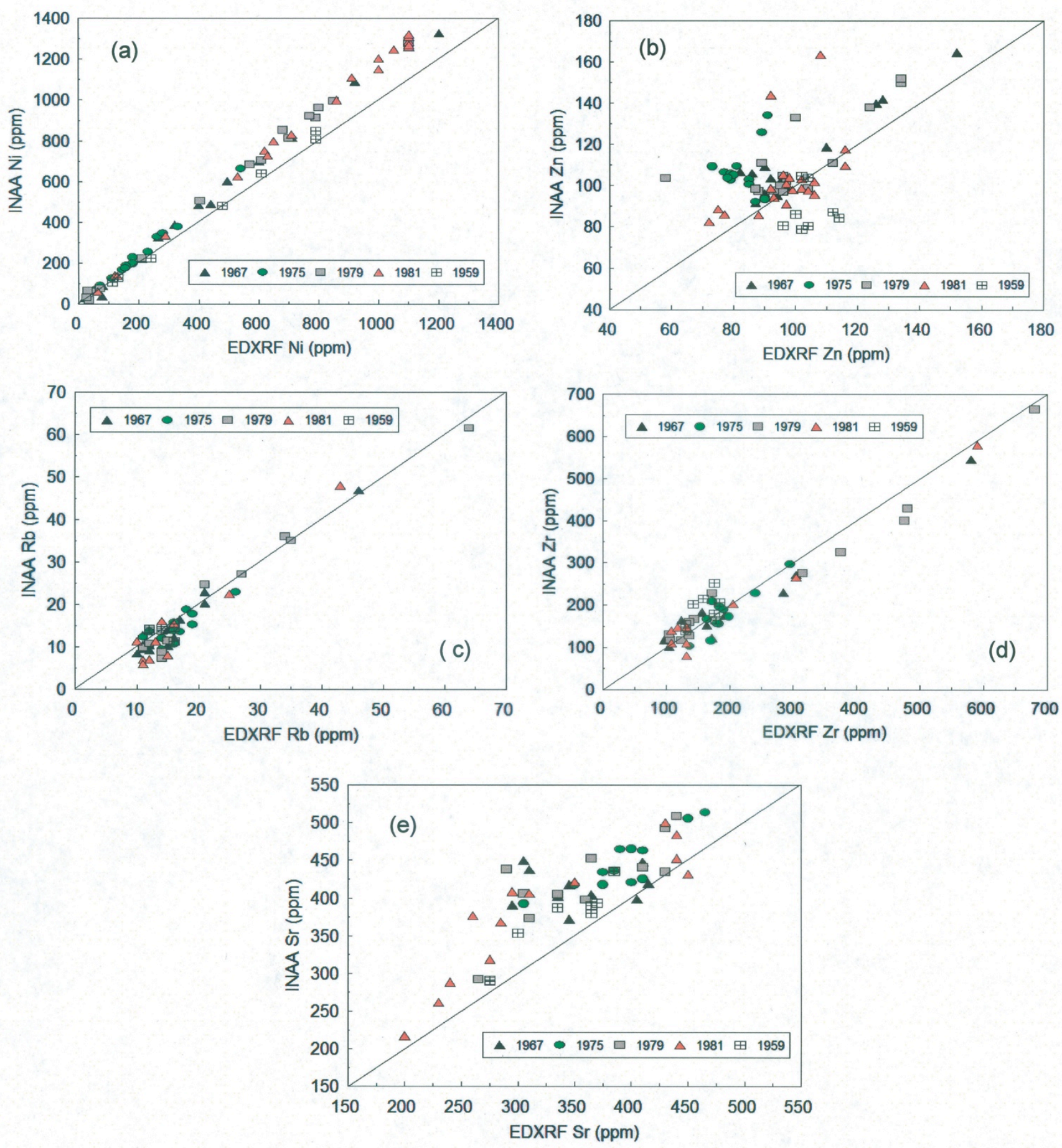

Figure 5. Plots comparing instrumental neutron-activation analysis (INAA) and energy-dispersive $X$-ray fluorescence (EDXRF) data for five elements from the present study. All quantities are in parts per million (ppm). 
Figures 5a and 5b compare INAA and EDXRF values for Ni and Zn, which are highly or mildly compatible with olivine. Ni concentrations are co-linear, with the INAA values mostly falling slightly above the 1:1 line, except for data from job CE92. By contrast, Zn data correlate very poorly; it is not clear from this plot which set gives the more satisfactory values for $\mathrm{Zn}$.

Figures 5c, 5d, and 5e show how Rb, Zr and Sr compare between the two analytical methods. The two highly incompatible elements $(\mathrm{Rb}, \mathrm{Zr})$ fall relatively close to the 1:1 line over a large range of concentrations, while the data for Sr correlate rather poorly, with the INAA values consistently higher than the EDXRF data.

Figure 6 shows that when INAA values for $\mathrm{Cr}$ are plotted against determinations for $\mathrm{Cr}_{2} \mathrm{O}_{3}$ included in earlier reports (Wright, 1973; Helz and others, 1994; Helz and Taggart, 2010), the data fall in a broad linear array. The data on older (1967-1981) cores and the 1959 samples were obtained colorimetrically (Kirschenbaum, 1983) or by flame atomic absorption (Aruscavage and Crock, 1987), as described in Helz and others (1994). They are consistent with each other and with the INAA analyses. The $\mathrm{Cr}_{2} \mathrm{O}_{3}$ data for the 1988 samples, which were obtained by inductively coupled plasma atomic emission spectroscopy (Lichte and others, 1987), tend to be high.

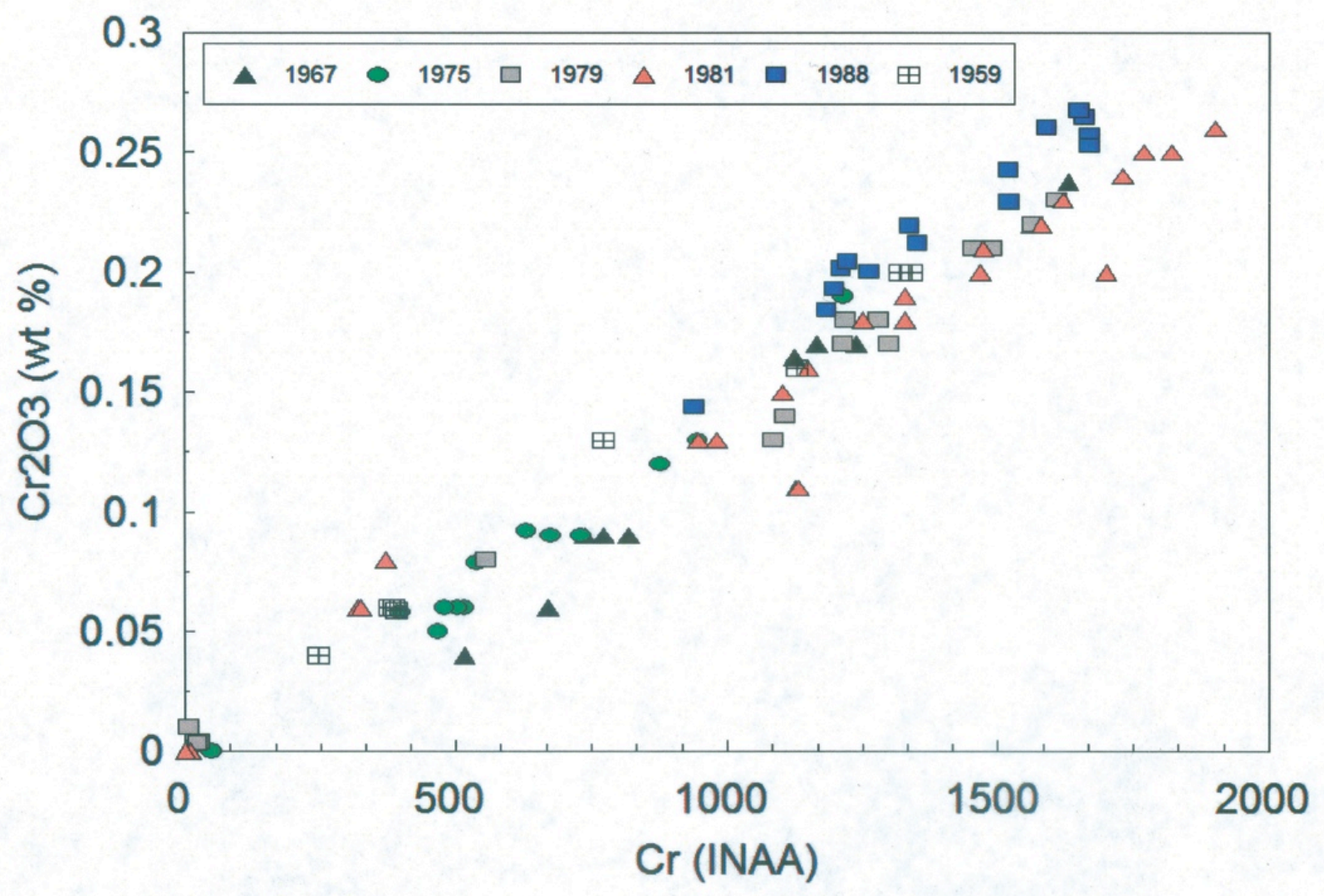

Figure 6. $\quad \mathrm{Cr}_{2} \mathrm{O}_{3}$ values (weight percent) plotted against instrumental neutron-activation analysis (INAA) determinations for $\mathrm{Cr}$ in parts per million for all samples in the present study. 


\section{Comparisons Among the 1959 Eruption Samples}

The 1959 summit eruption of Kilauea has been studied intensively for many years (Murata and Richter, 1966; Wright, 1973; Helz, 1987a), and some samples from the eruption were previously analyzed for trace elements by Gunn (1971) and Tilling and others (1987), as summarized in table 1. This section will use these results plus the new data to evaluate the results in the context of what is known about the petrology of the 1959 eruption samples.

The 1959 eruption was picritic, with most samples consisting of vesicular brown glass and varying amounts of olivine and chromite (Richter and Murata, 1966; Helz, 1987a). The trace-element variations reflect this limited crystalline assemblage, as discussed in Gunn (1971). Thus all samples would be expected to fall on straight lines in magnesia variation diagrams (Wright, 1971; Wright, 1973).

Figures 7a and 7b show how element concentrations for Ni and Co (fig. 7a) and Zn (fig. 7b) vary as a function of $\mathrm{MgO}$ content. These divalent cations enter olivine to varying extents: Ni is strongly compatible, decreasing markedly as bulk MgO content (and hence olivine phenocryst content) decreases. Three of four analytical sets have similar Ni values; those of Tilling and others (1987), made in the developmental phase of the INAA technique, run low at higher MgO contents. Co decreases slightly but perceptibly as $\mathrm{MgO}$ decreases, while $\mathrm{Zn}$ is so noisy it is not clear whether the slope is positive or negative. Of the four data sets, those of Gunn (1971) and the EDXRF data of the present study are in agreement with each other, suggesting that these are the best values available.

Figures $7 \mathrm{c}-\mathrm{e}$ show how the concentrations of six elements incompatible with olivine vary as a function of $\mathrm{MgO}$ content in the 1959 samples. The concentration of these elements increases as $\mathrm{MgO}$ decreases, as would be expected. In figure 7c, the Sr data are somewhat noisy, with the Gunn (1971) and the EDXRF data showing the least scatter. Two (of four) Sr points from Tilling and others (1987) are in good agreement with the other sets, but the two less magnesian samples run low, confirming the suggestion of Tilling and others (1987) that their Sr determinations were suspect. By contrast, the Ba data are coherent for all three available data sets. The Rb data of the present study (fig. 5c), though in good agreement with each other, are somewhat higher than the Gunn (1971) data, as indicated in table 1.

Figure 7d (Sc, La and Hf) show that the INAA data for these incompatible, high-field-strength elements from Tilling and others (1987) are in good agreement with the INAA data of the present study. For similar elements not plotted here, the other rare-earth elements follow La, and the U levels also compare reasonably well, as indicated in table 1. By contrast, the Y data (fig. 7e) are noisy, and no two studies fall at the same concentration level, though the Gunn (1971) data seem to define the most coherent olivine-control line.

To summarize, most of the available trace-element data for samples from the 1959 eruption fall on linear arrays consistent with olivine control, even for elements where the different studies have obtained different concentration levels. Given that the samples consist of glass \pm olivine \pm chromite, the few data sets (some $\mathrm{Zn}$ and $\mathrm{Y}$ data) that do not define linear arrays must be regarded as of lower quality than those that do. 

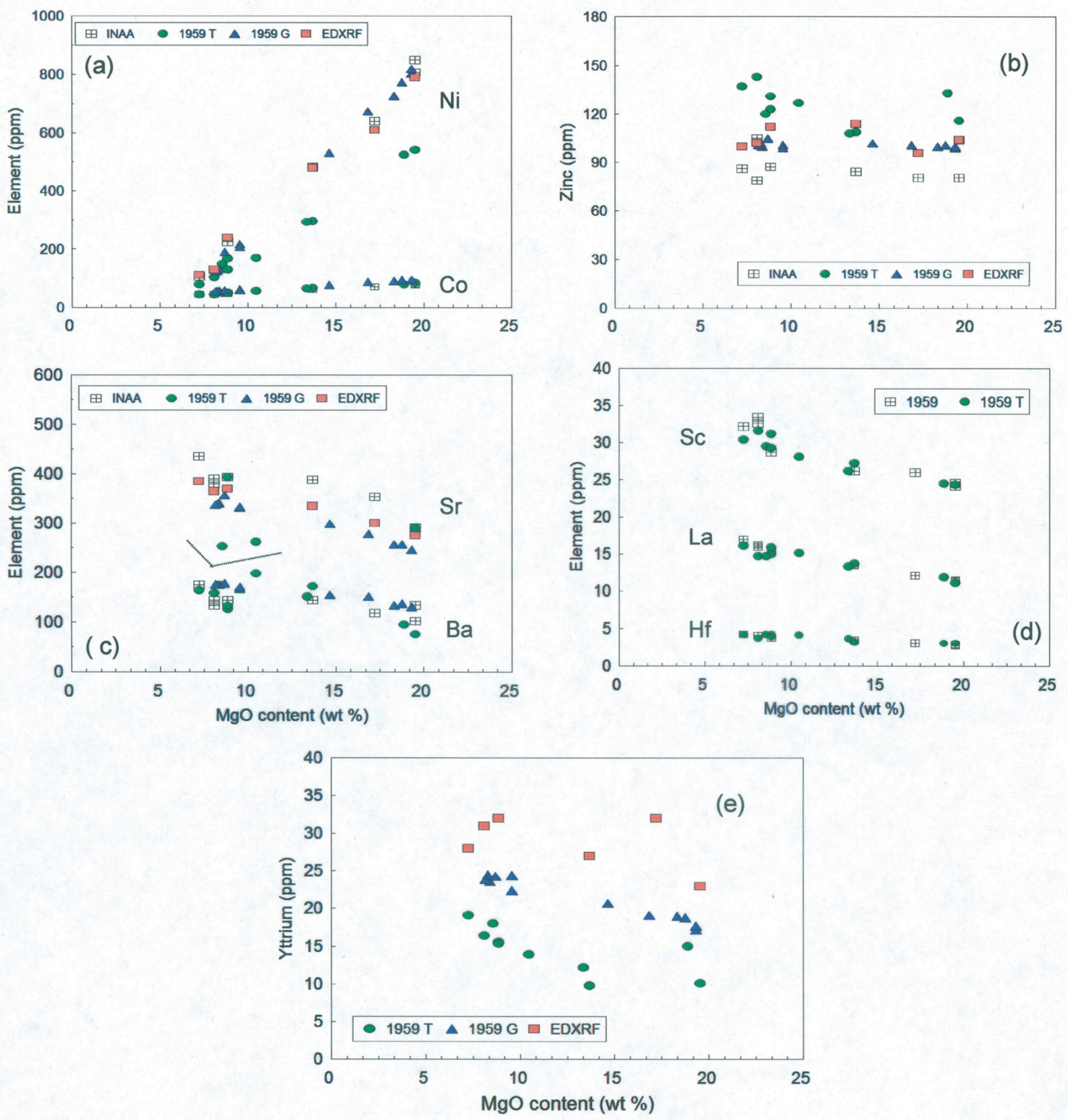

Figure 7. Concentrations of nine elements, in parts per million (ppm), plotted against $\mathrm{MgO}$ content, in weight percent ( $w t \%)$, for samples from the 1959 eruption. Up to four different data sets are available, as indicated in the key within each plot. 


\section{Overview of Processes Active in Kilauea Iki Lava Lake}

Of the 84 samples included in this study, 78 are samples of drill core from Kilauea Iki lava lake, recovered from 1967 to 1988. Most are olivine-phyric basalt, but a few segregation veins and other internal differentiates and borehole oozes have been included to help flesh out the behavior of trace elements over the lower part of the line of descent of the fractionating liquid. In contrast to the eruption samples, which differ primarily in their olivine content, samples from the lava lake have been affected by lower-temperature processes where augite and plagioclase were also present as crystallizing phases.

Table 2 summarizes the processes that have affected Kilauea Iki samples, as described in Helz (1987a, 2009). The olivine content of the olivine-phyric samples varies greatly, with bulk MgO content in this suite ranging from 6.74 to over 25 percent. More of the lake has been affected by this process than any other, as indicated in table 2. The second most significant process is the upward migration of the low-density liquid present at the beginning of crystallization of plagioclase as described in Helz and others (1989). Most of the 78 lava lake samples have been affected by one or both of these processes, which took place in the molten core of the lake.

Table 2. Differentiation processes in Kilauea Iki lava lake, modified from Helz (1987a, 2009). $[+$, plus; >, greater than; <, less than]

\begin{tabular}{|c|c|c|c|}
\hline Stage of crystallization & Differentiation process & $\begin{array}{c}\text { Depth range } \\
\text { affected (meters) }\end{array}$ & $\begin{array}{l}\text { Temperature } \\
\text { range }\left({ }^{\circ} \mathrm{C}\right)\end{array}$ \\
\hline \multirow{3}{*}{$\begin{array}{l}\text { Processes occurring in } \\
\text { molten core of lake, before } \\
\text { formation of coherent } \\
\text { crystal mush }\end{array}$} & Olivine settling & 10 to $97+$ & $>1180$ \\
\hline & Lateral convection & 20 to 43 & 1165-1170 \\
\hline & $\begin{array}{l}\text { Diapiric melt transfer of } \\
\text { minimum-density melt }\end{array}$ & 13 to 94 & $1150-1160$ \\
\hline \multirow[t]{3}{*}{$\begin{array}{l}\text { Processes occurring within } \\
\text { coherent crystal mush } \\
\text { zones }\end{array}$} & $\begin{array}{l}\text { Formation of ferrodiabasic } \\
\text { segregation veins (coarse grained, } \\
\text { sill-like, internal differentiates) }\end{array}$ & 18 to 56 & 1100-1135 \\
\hline & $\begin{array}{l}\text { Formation of vertical olivine-rich } \\
\text { bodies (diapir tracks) that carried } \\
\text { segregation vein melts through the } \\
\text { mush zone at the base of the upper } \\
\text { crust }\end{array}$ & 18 to 58 & $<1140$ \\
\hline & $\begin{array}{l}\text { Formation of melt chimneys and } \\
\text { speckled-rock plumes that carried } \\
\text { differentiated melts upward from the } \\
\text { lower mush zone atop the lower crust }\end{array}$ & 78 to 95 & $<1140$ \\
\hline $\begin{array}{l}\text { Process occurring in rigid } \\
\text { but partially molten rock }\end{array}$ & $\begin{array}{l}\text { Flow of late-stage melts into fractures } \\
\text { and open boreholes }\end{array}$ & $\begin{array}{l}\text { Possible } \\
\text { anywhere inside } \\
\text { chilled margins }\end{array}$ & $<1070$ \\
\hline
\end{tabular}


Lower-temperature processes include the formation of diabasic segregation veins and of the vertical structures that mark the passage of the ferrodiabasic liquid from the lower part of the lake to the upper parts. These processes, which occur within coherent crystal mush zones (table 2), leave conspicuous textural traces in the drill core. The suite of samples analyzed here includes four ferrodiabasic segregation veins and three oozes of similar composition, plus four samples of rocks having anomalous textures and compositions (two vertical olivine-rich bodies or "vorbs", one olivineglass body, and one speckled-rock body) that mark them as having been zones of transport for the segregation-vein liquids.

The final process in table 2, which has produced the most extreme differentiates found in Kilauea Iki, is the flow of late-stage melts into naturally occurring fractures in the lake or, occasionally, into open boreholes. Table 3 presents bulk compositional data for all samples more fractionated than the ferrodiabasic segregation veins, for which data are included in this report.

The table includes three samples with $\mathrm{MgO}=2.37-2.60$ percent, two of which formed from melt found within segregation veins that had half-crystallized. One of these (KI67-2-85.7) flowed from a partially molten segregation into an open borehole and was recovered during redrilling. The other (KI81-2-88.6) is a naturally occurring internal differentiate of a segregation vein, of similar composition. The third extremely differentiated sample is KI79-5-163.0, shown in column 1 of table 3. This small vein formed when liquid flowed not from a partly crystallized segregation vein but from within olivine-rich matrix when the matrix fractured somewhat above its solidus.

This vein was too small to submit for major-element as well as trace-element analysis, so some of the powder was fused in a nitrogen atmosphere at extremely high temperature using the procedure of Jezek and others (1979), and the resulting glass was analyzed by microprobe. This same technique was applied to powder of sample KI81-2-88.6. Comparison of the analyses in columns 2 and 3 of table 3 shows that microprobe analysis of the fused glasses produces a reasonably accurate bulk composition for KI81-2-88.6, which suggests that the analysis in column 1 fairly represents the composition of sample KI79-5-163.0. If one compares this bulk composition with the various liquid lines of descent shown in Helz (1987a), the $\mathrm{Al}_{2} \mathrm{O}_{3}$, total iron as $\mathrm{FeO}$, and $\mathrm{CaO}$ contents of KI79-5-163.0 are consistent with its having been interstitial liquid in an olivine-rich matrix, like the melts from KI81-1. By contrast, the other two extreme differentiates have compositions that mark them as derived from an olivine-poor source, like liquids from KI67-3, consistent with their occurrence as internal differentiates of segregation veins.

The final two columns in table 3 show bulk compositions of two melt-rich layers from the ooze that rose in borehole KI79-1, recovered as core KI79-1R (see descriptive log in Helz, 1993). This ooze underwent flow differentiation as it moved up, liberating an intermediate-stage liquid $(\mathrm{MgO}=3.42-$ 3.48 percent) that does not otherwise occur as a separate body in Kilauea Iki. These compositions are consistent with interstitial melts from intermediate olivine contents, like those from KI75-1 (Helz, 1987a). 
Table 3. Major-element compositions of extreme differentiates from Kilauea lki for which trace-element data have been obtained. The whole-rock gravimetric analyses are from Helz and others (1994), although here all iron is reported as FeO to facilitate comparison with the microprobe analyses.

[ ---, no data; <, less than]

\section{1}

\begin{tabular}{|c|c|c|c|c|c|c|}
\hline Sample no. & $\begin{array}{c}\text { KI79-5-163.0 } \\
\text { small vein }\end{array}$ & $\begin{array}{l}\text { KI81-2-88.6 vein in } \\
\text { segregation vein }\end{array}$ & $\begin{array}{l}\text { KI81-2-88.6 vein in } \\
\text { segregation vein }\end{array}$ & $\begin{array}{c}\text { KI67-2-85.7 00ze } \\
\text { from segregation } \\
\text { vein }\end{array}$ & $\begin{array}{l}\text { KI79-1R1-167.8 } \\
\text { melt layer } \\
\text { in ooze }\end{array}$ & $\begin{array}{l}\text { KI79-1R1-170.9 } \\
\text { melt layer } \\
\text { in ooze }\end{array}$ \\
\hline $\begin{array}{l}\text { Type of } \\
\text { analysis }\end{array}$ & $\begin{array}{l}\text { Fused glass } \\
\text { microprobe }\end{array}$ & $\begin{array}{l}\text { Fused glass } \\
\text { microprobe }\end{array}$ & Gravimetric & Gravimetric & Gravimetric & Gravimetric \\
\hline $\mathrm{SiO}_{2}$ & 60.11 & 56.56 & 57.07 & 56.21 & 54.78 & 54.59 \\
\hline $\mathrm{Al}_{2} \mathrm{O}_{3}$ & 14.18 & 12.86 & 12.86 & 12.88 & 13.22 & 13.01 \\
\hline $\mathrm{FeO}$ (total) & 7.59 & 11.70 & 11.61 & 12.03 & 11.63 & 11.97 \\
\hline $\mathrm{MgO}$ & 2.57 & 2.50 & 2.37 & 2.60 & 3.42 & 3.48 \\
\hline $\mathrm{CaO}$ & 4.51 & 6.11 & 6.08 & 6.33 & 7.08 & 7.07 \\
\hline $\mathrm{Na}_{2} \mathrm{O}$ & 4.25 & 3.50 & 3.55 & 3.53 & 3.41 & 3.37 \\
\hline $\mathrm{K}_{2} \mathrm{O}$ & 2.59 & 2.02 & 1.90 & 1.99 & 1.52 & 1.51 \\
\hline $\mathrm{H}_{2} \mathrm{O} \pm$ & ---- & ---- & 0.18 & 0.32 & 0.26 & 0.21 \\
\hline $\mathrm{TiO}_{2}$ & 2.16 & 2.56 & 2.59 & 2.72 & 3.24 & 3.21 \\
\hline $\mathrm{P}_{2} \mathrm{O}_{5}$ & 0.66 & 0.84 & 0.96 & 0.88 & 0.74 & 0.69 \\
\hline $\mathrm{MnO}$ & 0.08 & 0.14 & 0.18 & 0.20 & 0.18 & 0.19 \\
\hline $\mathrm{Cr}_{2} \mathrm{O}_{3}$ & $<0.01$ & $<0.01$ & $<0.01$ & 0.00 & $<0.01$ & $<0.01$ \\
\hline Total & 98.70 & 98.79 & 99.35 & 99.69 & 99.48 & 99.30 \\
\hline
\end{tabular}




\section{Trace-Element Variations in Kilauea Iki Lava Lake}

Chemical variations in Kilauea Iki are most effectively presented on magnesia variation diagrams because of the large range of values for MgO. Such plots of the major elements show clearly the dominance of olivine control but also allow one to recognize the incoming of augite, plagioclase, and the Fe-Ti oxides (Helz and others, 1994). The following section discusses the variation of 16 trace elements versus $\mathrm{MgO}$, selected to include all variation patterns observed. Elements omitted include the rare-earth elements (REE), whose chondrite-normalized patterns are discussed in a separate section below, and elements that were below the level of detection in many samples. The principal conclusions of this report are that there are few surprises in the trace-element data and that variations in the data are consistent with processes already inferred from major-element variations documented in earlier studies (Helz, 1987a; Helz and others, 1989; Helz, 2009).

\section{Trace Elements Compatible with Olivine and (or) Chromite}

The variations of $\mathrm{Cr}, \mathrm{Ni}$, and $\mathrm{Zn}$ as a function of $\mathrm{MgO}$ content are shown in figures 8a-c, with $\mathrm{Cu}$ versus $\mathrm{MgO}$ shown for comparison in figure 8d. Of these, Ni (like Co, which is not shown separately here) shows the simplest pattern, decreasing steadily as $\mathrm{MgO}$, and hence the olivine content of the samples, decreases. There is no divergence between the 1959 eruption samples and cores drilled in various years.

Cr displays a similar overall decrease because most $\mathrm{Cr}$ is in chromite, and chromite occurs primarily as inclusions in olivine. However, a small group of very magnesian samples (outlined in fig. 8a) have relatively low Cr contents. These analyses (of samples 79-3-145.1, 81-1-169.9, 81-1-200.4, and 88-1-268.5) are all of structures related to the formation of segregation veins, as noted in the analytical tables. They are enriched in interstitial melt and depleted in augite relative to normal matrix rock with similar bulk MgO contents, hence their relatively low $\mathrm{Cr}$ levels. Finally, it should be noted that $\mathrm{Cr}$ shows a sudden drop to nearly zero for samples with $\mathrm{MgO}<6.5$ percent (the segregation veins and more extreme differentiates), presumably because they contain little olivine and no chromite. The more gradual decrease seen for $\mathrm{Ni}$ in the less magnesian samples may reflect the presence of some $\mathrm{Ni}$ in pyroxenes.

Figure 8c shows the EDXRF data for Zn, as they are more coherent than the INAA data and are consistent with Gunn's (1971) data. In the eruption samples, Zn increases very slightly as MgO content decreases, suggesting that $\mathrm{Zn}$ is only slightly fractionated between forsteritic olivine (average composition $\mathrm{Fo}_{86-87}$ ) phenocrysts and the melt, as noted earlier by Gunn (1971). However, in core from Kilauea Iki, Zn clearly decreases throughout the olivine-control range ( $\mathrm{MgO}=6.5-27.5$ percent). In this range, $\mathrm{Zn}$ is partitioned into the Fe-enriched olivine produced by re-equilibration of the original

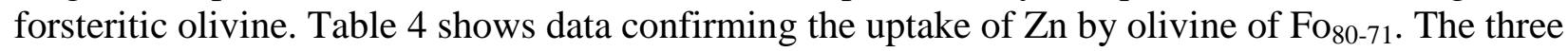
samples highlighted in figure 8c, which run higher in Zn than most, are also enriched in Fe-rich olivine relative to other samples with similar MgO contents. Below 6.5 percent MgO, Zn increases significantly (peaking at 150 parts per million), then drops in the most extreme differentiates. The increase presumably reflects the paucity of olivine in the fractionating assemblage in the range of 3.5 to 6.5 percent $\mathrm{MgO}$. The subsequent decline in $\mathrm{Zn}$ is presumably caused by partitioning of $\mathrm{Zn}$ into one or more of the Fe-Ti oxide minerals that begin to crystallize at 4.5-5.5 percent MgO (Helz, 1987a; Helz and others, 1994). 

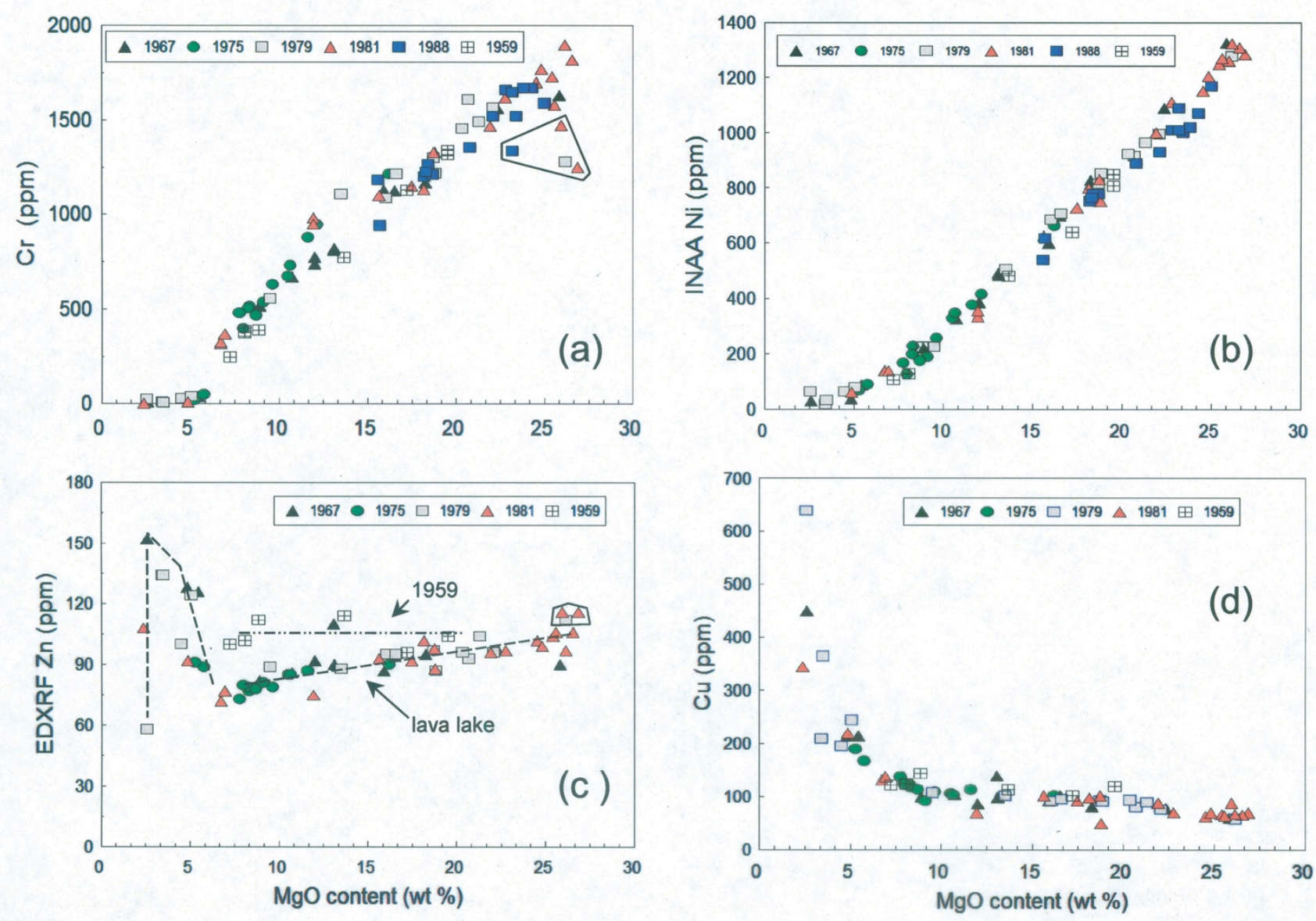

Figure 8. $\mathrm{Cr}, \mathrm{Ni}, \mathrm{Zn}$, and $\mathrm{Cu}$ concentrations, in parts per million (ppm), versus $\mathrm{MgO}$ content, in weight percent (wt \%), for drill core plus samples from the 1959 eruption, as indicated in the key within each plot. Fields in figures $8 \mathrm{a}$ and $8 \mathrm{c}$ enclose melt-enriched samples from structures associated with the formation of segregation veins. Lines in figure 8c show Zn compositional trends, as discussed in the text. 
Table 4. Average olivine compositions in selected samples from Kilauea lki lava lake.

[Quantities in weight percent unless otherwise noted. ${ }^{\circ} \mathrm{C}$, degrees Celsius; ppm, parts per million; mol \%, mol percent]

\begin{tabular}{|c|c|c|c|c|}
\hline $\begin{array}{l}\text { Sample no. } \\
\text { Temperature on } \\
\text { quench }\left({ }^{\circ} \mathrm{C}\right) \\
\text { No. points }\end{array}$ & $\begin{array}{c}\text { KI67-3-83.8 } \\
1076\end{array}$ & $\begin{array}{c}\text { KI75-1-144.9 } \\
1117\end{array}$ & $\begin{array}{c}\text { KI79-3-166.1 } \\
1071 \\
11\end{array}$ & $\begin{array}{c}\text { KI79-1-187.4 } \\
1130 \\
12\end{array}$ \\
\hline $\mathrm{SiO}_{2}$ & 37.90 & 39.10 & 38.76 & 39.14 \\
\hline $\mathrm{TiO}_{2}$ & 0.03 & 0.02 & 0.03 & 0.02 \\
\hline $\mathrm{Al}_{2} \mathrm{O}_{3}$ & 0.01 & 0.03 & 0.02 & 0.02 \\
\hline $\mathrm{Cr}_{2} \mathrm{O}_{3}$ & 0.01 & 0.02 & 0.02 & 0.03 \\
\hline $\mathrm{FeO}$ & 25.59 & 19.82 & 21.35 & 18.51 \\
\hline $\mathrm{NiO}$ & 0.20 & 0.26 & 0.26 & 0.27 \\
\hline $\mathrm{MnO}$ & 0.34 & 0.28 & 0.30 & 0.27 \\
\hline $\mathrm{MgO}$ & 36.19 & 41.12 & 39.86 & 41.78 \\
\hline $\mathrm{CaO}$ & 0.28 & 0.28 & 0.26 & 0.29 \\
\hline Total & 100.57 & 100.94 & 100.88 & 100.33 \\
\hline Zn (ppm) & 154 & 121 & 140 & 96 \\
\hline Fo (mol \%) & 71.4 & 78.5 & 76.8 & 79.9 \\
\hline
\end{tabular}

This complex behavior for Zn contrasts strongly with that of $\mathrm{Cu}$ (figure 8d), which is included here for comparison and exhibits the pattern of an incompatible trace element. Copper is chalcophile, of course, but the melt becomes saturated with immiscible sulfide liquid at so late a stage that sulfide is not a fractionating phase. The sample with the highest $\mathrm{Cu}$ content is the small vein KI79-5-163.0 (col. 1, table 3), which contains a number of blebs of pure chalcocite $\left(\mathrm{Cu}_{2} \mathrm{~S}\right)$, as documented in Pitcher and others (2009).

\section{Trace Elements Compatible with Pyroxene and (or) Plagioclase}

Only two elements in the suite investigated (Sc and Sr, in figs. 9a and 9b) show discernible effects of crystallization and fractionation of augite or plagioclase in magnesia variation diagrams. The first of these (Sc) peaks at roughly 7 to 8 percent $\mathrm{MgO}$. As augite begins to crystallize (at $\mathrm{MgO}=7.5$ to 7.6 percent, Helz and Thornber, 1987), trivalent Sc is partitioned strongly into this new phase. Sc levels decrease sharply as augite crystallization proceeds, as can be seen in the Sc levels in samples with less than 5 percent $\mathrm{MgO}$, in which the dominant pyroxene is pigeonite.

The EDXRF data for Sr (fig. 9b) are shown rather than the INAA data for Sr because they are much more coherent, though lacking data for the 1988 drill core. Strontium levels peak at $\mathrm{MgO}=6-7$ percent, where plagioclase begins to crystallize. Strontium then decreases slightly but not as drastically as Sc. This is because (1) it is not as strongly partitioned into plagioclase as Sc is into augite and (2) the most differentiated samples analyzed are still crystallizing abundant plagioclase, whereas augite crystallization is nearly complete. 

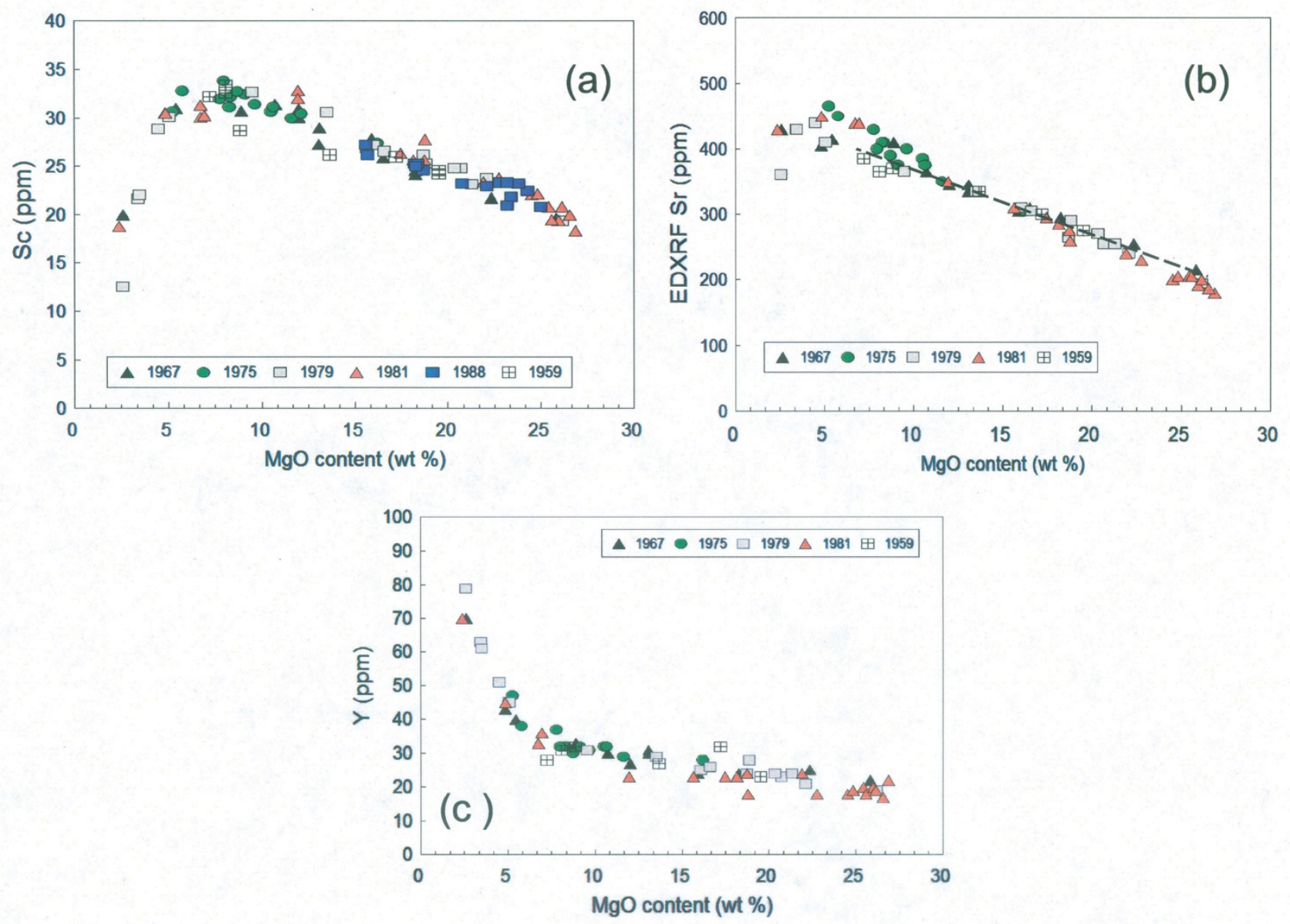

Figure 9. Sc, Sr, and $\mathrm{Y}$ concentrations, in parts per million (ppm), versus $\mathrm{MgO}$ content, in weight percent (wt \%), for drill core samples plus samples from the 1959 eruption, as indicated in the key within each plot. Dashed line in figure $9 \mathrm{~b}$ indicates olivine-control line, based on the 1959 eruption samples plus sample KI67-3-6.8, as discussed in the text.

The dashed line in figure 9b fits the 1959 eruption samples plus KI67-3-6.8, a very olivine-rich sample recovered at a depth of 6.8 feet in 1967, from the upper chill zone of the lava lake. These

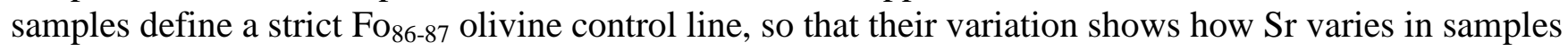
affected only by olivine control. Note that the slope of this line is shallower than the overall array of samples from the lava lake. This is a recurring feature of the trace-element data, as it was for the relatively incompatible major elements $\left(\mathrm{TiO}_{2}, \mathrm{Na}_{2} \mathrm{O}, \mathrm{K}_{2} \mathrm{O}, \mathrm{P}_{2} \mathrm{O}_{5}\right.$, as discussed in Helz and Taggart, 2010). This rotation in trends is consistent with the migration of differentiated liquid upward in the lake (Helz, 1987a; Helz and others, 1989), as summarized in table 2. That line is not shown in figure 9a because the eruption samples are quite variable in their Sc levels, perhaps reflecting the two different components of this mixed-magma eruption (Wright, 1973; Helz, 1987b).

Figure 9c shows the variation of yttrium with MgO for all available data, for comparison with Sc. In spite of the incoherence of the various Y determinations for the 1959 eruption samples (fig. 7e), the overall pattern for $\mathrm{Y}$ in the lava lake is reasonably coherent, presumably because the range of concentrations of both $\mathrm{Y}$ and $\mathrm{MgO}$ are larger in figure 9c than those in figure 7e. The pattern, as expected, is that of a relatively incompatible trace element. 


\section{Incompatible Alkali and Alkaline Earth Trace Elements}

Figure 10 shows how $\mathrm{Rb}, \mathrm{Ba}$, and Cs vary as a function of MgO content in the Kilauea Iki samples. The INAA data for Rb are shown because (1) there are INAA analyses of the 1988 drill core and (2) the two methods produced data sets of similar coherence. Both Rb and Ba are excluded from all fractionating phases in the lava lake, so they are strongly enriched in the most differentiated samples. The dashed lines in figures 10a and 10b are olivine control lines determined as in figure 9b. There is some divergence between the line and the array of lava lake samples for $\mathrm{Ba}$, but very little for $\mathrm{Rb}$.

The available Cs data are shown in figure 10c. There is a scattering of Cs values reported in tables A2-A6; in addition, table A1 contains Cs determinations made by recounting one group of samples months later (job CE92), as described above. The recount data fall on a plausible olivinecontrol line, suggesting that this later counting produces more reliable Cs numbers than the standard procedure.
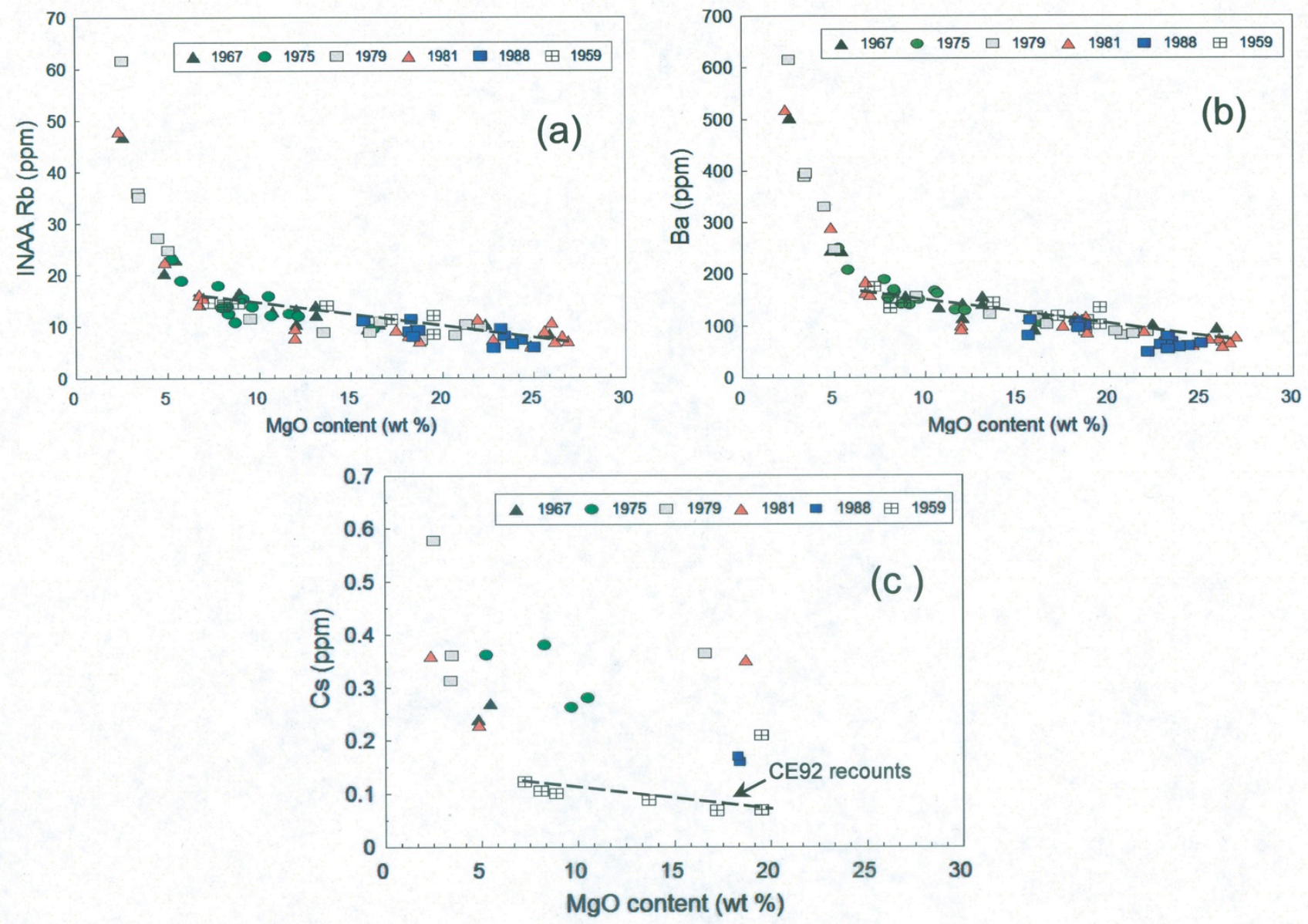

Figure 10. $\mathrm{Rb}, \mathrm{Ba}$, and $\mathrm{Cs}$ concentrations, in parts per million (ppm), versus $\mathrm{MgO}$ content, in weight percent (wt \%), for drill core samples plus samples from the 1959 eruption, as indicated by the key within each plot. Dashed lines in figures 10a and 10b are olivine-control lines, as discussed in the text. Figure 10c shows Cs for the few samples where Cs was reported. 


\section{High Field Strength Trace Elements}

Figures 11a-f show magnesia variation diagrams for some high field strength elements (HFSE) other than the rare earths. Their patterns are all very similar in spite of large differences in concentration range among these elements. For the more tightly coherent elements ( $\mathrm{Zr}$, Hf, Ta, Th), the olivine-control line determined from the eruption samples plus KI67-3-6.8 is shown. The line is omitted for Nb and U because the reported values for the 1959 samples are more dispersed.

The array of data from the lava lake shows a consistent steeper slope than the strict olivinecontrol line, consistent again with extensive upward migration of differentiated liquid in the lake, as summarized in table 2. A unique feature of this group of trace elements is that a small group of samples from deep in the lava lake is depleted in these HFSE relative to most of the array. These samples include 81-1-270, 81-1-273.6 and 88-2-301.7 from zone VI (as noted in the analytical tables) and 88-2-322.2 (from zone VII). This extra level of depletion, seen also in $\mathrm{K}_{2} \mathrm{O}$ and $\mathrm{P}_{2} \mathrm{O}_{5}$ levels, was attributed (Helz and Taggart, 2010) to these samples having lost more segregation-vein liquid than most other samples from similar depths. This second type of liquid extraction (table 2) involves a lower-temperature, more differentiated liquid than the migration of minimum-density melt. The higher-temperature process operated more uniformly on sections of the lake affected, as discussed in Helz and others (1989). By contrast, the lower-temperature segregation-liquid extraction is more local and more variable in its effects. 

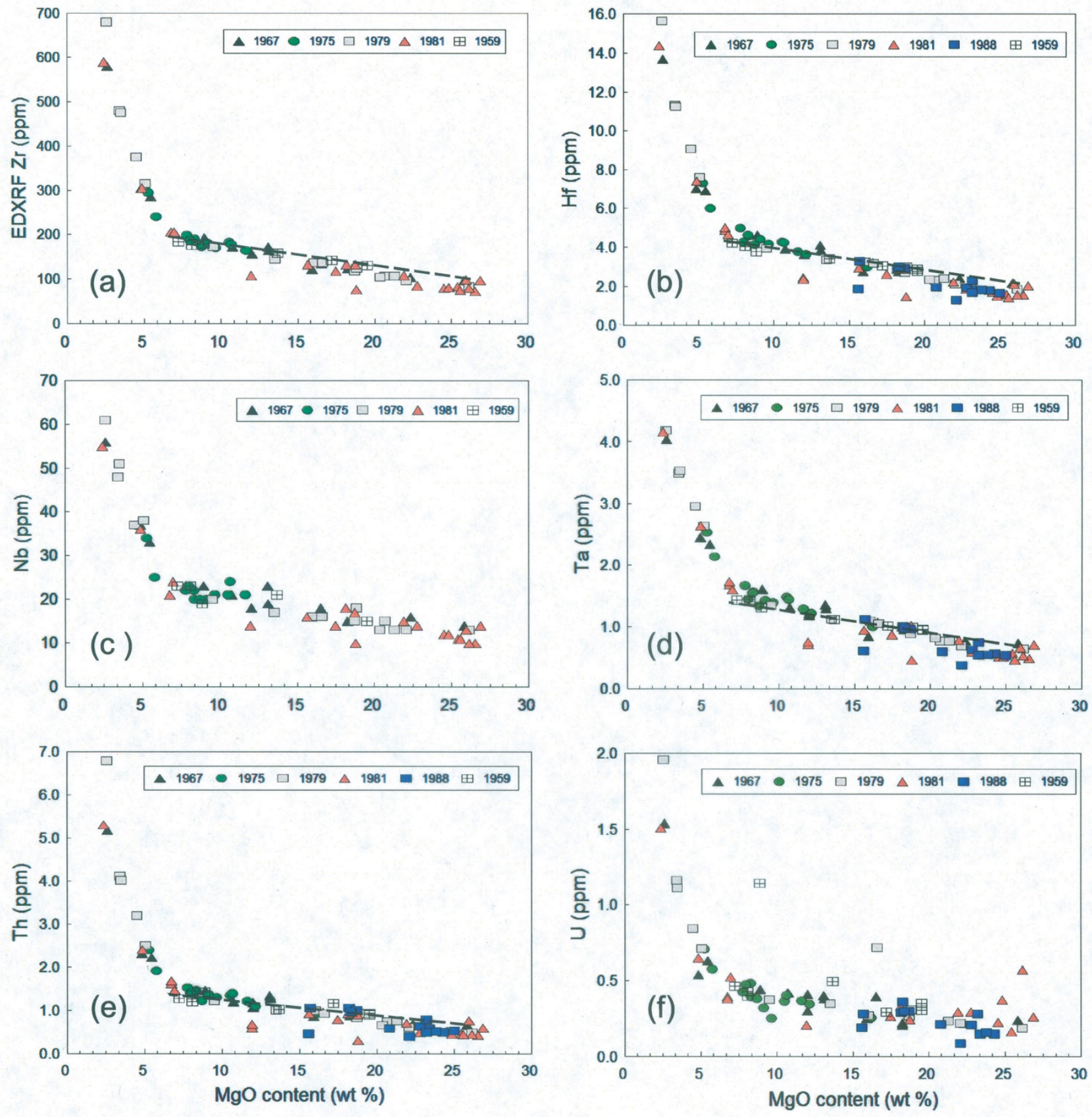

Figure 11. Trace elements, in parts per million (ppm), versus $\mathrm{MgO}$ contents, in weight percent (wt \%), for drill core plus samples from the 1959 eruption, as indicated in the key within each plot. Dashed olivine-control lines, as in figure $9 b$, are discussed in the text. 


\section{Chondrite-Normalized Rare-Earth Element Patterns}

Variations in rare-earth elements (REE) are usually displayed in diagrams where the concentrations of the REE in the various samples have been divided by the REE concentrations in chondrites. Figures 12 and 13 present REE patterns for selected samples from the present study, normalized using the REE concentrations reported in Anders and Ebihara (1982).

Figure 12 shows REE patterns for the 1959 eruption samples (table A1) plus that for sample 67-3-6.8 (table A2). This group of samples is used to define the olivine-control lines shown in several previous figures. Most patterns show a smooth decline in REE from La to Lu, with the patterns being slightly convex upward in the middle and declining steadily in the heavy REE. This pattern appears to be typical for Kilauea basalts (see, for example, Leeman and others, 1980), although it should be noted that this reference and most other collections of trace-element data for Kilauea lavas include a disproportionate number of samples from the 1959 eruption itself. REE concentration levels are inversely proportional to the olivine content of the samples, with sample 67-3-6.8 (MgO = 25.83 percent) being lowest and Iki-1 ( $\mathrm{MgO}=7.23$ percent) being highest in REE.

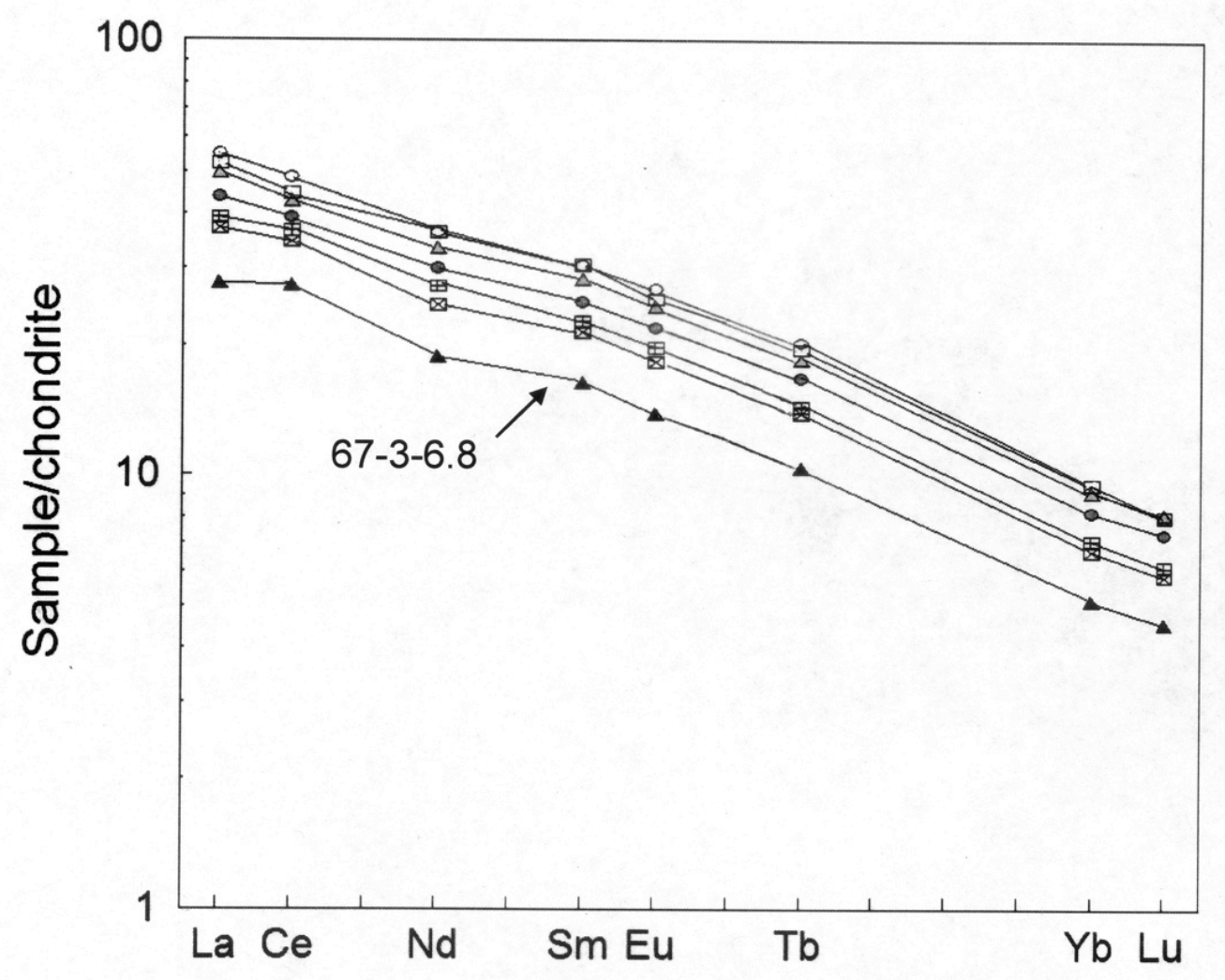

Figure 12. Chondrite-normalized rare-earth element (REE) patterns for samples from the 1959 eruption plus shallow sample 67-3-6.8. 
Figure 13 includes data for two groups of extreme samples from Kilauea Iki lava lake in order to show the effects of internal differentiation on the REE patterns. The upper group of samples (those with $\mathrm{La}=80-115$ times chondrite) include all segregation veins and equivalent glasses (five samples) plus the five more extreme differentiates shown in table 3. These samples again show that, in general, REE levels increase as MgO content decreases, although the single most REE-enriched sample is 79-5-163.0, which has slightly more $\mathrm{MgO}$ than the internal differentiates from segregation veins (table 3).

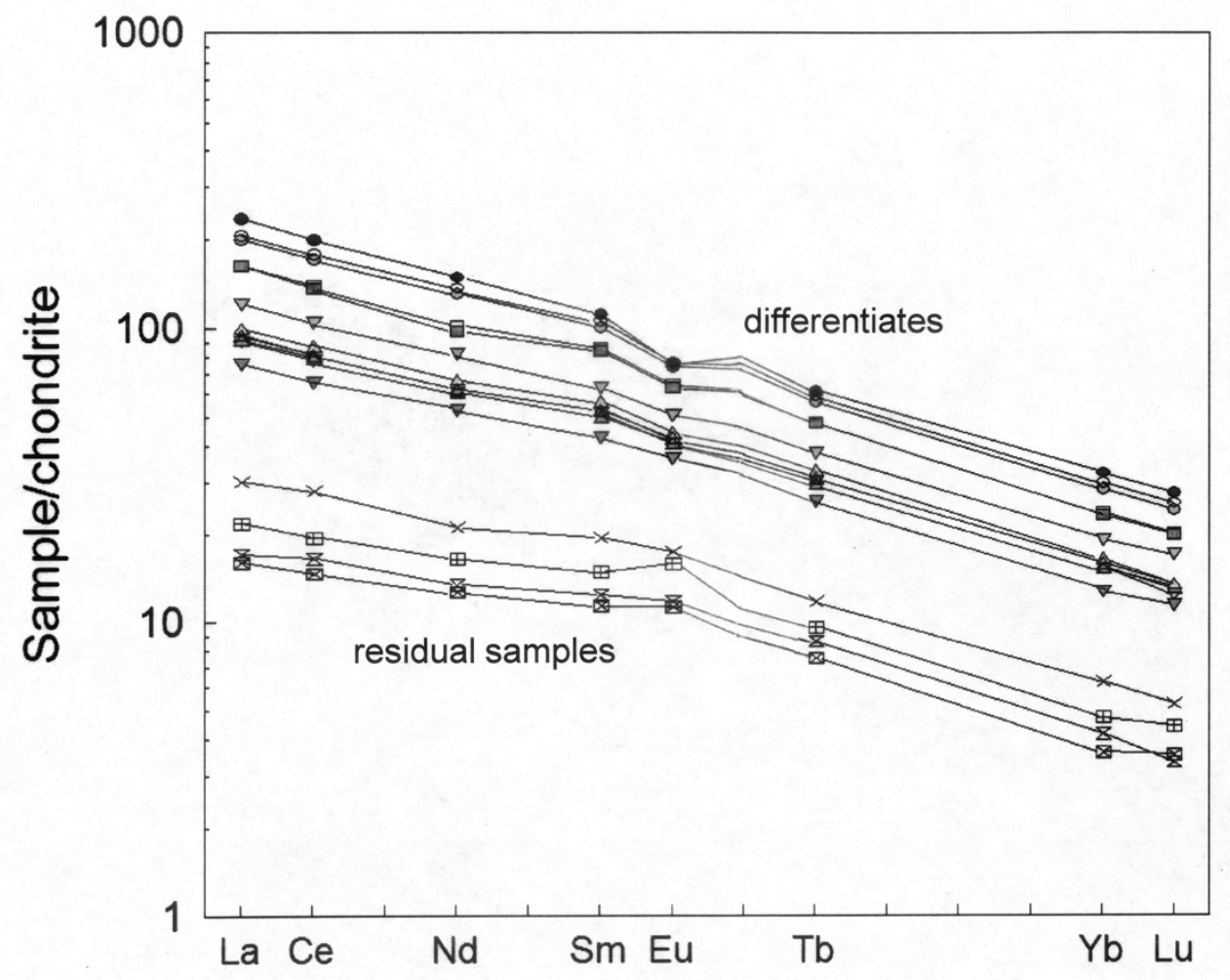

Figure 13. Chondrite-normalized rare-earth element (REE) patterns for segregation veins and glasses (five triangles), differentiated oozes from KI79-1R (two rectangles) and small late veins and oozes (three ovals), together with four strongly depleted samples from zones VI and VII.

The segregation-vein patterns have barely perceptible negative Eu anomalies, but the five more differentiated samples are clearly depleted in Eu relative to adjacent REE. Such negative Eu anomalies occur because the fraction of Eu present as $\mathrm{Eu}^{+2}$ is fractionated by plagioclase. The ratio of divalent to trivalent Eu varies inversely with oxygen fugacity, so that Eu anomalies are more easily generated at low oxygen fugacity (Drake, 1975; Drake and Weill, 1975). Oxidation conditions in Kilauea Iki lava lake vary from fayalite-magnetite-quartz (FMQ) to nickel-nickel oxide (NNO), based on compositions of coexisting ilmenite and magnetite (Buddington and Lindsley, 1964), so Eu anomalies are not conspicuous. They are discernible in the segregation veins but are best developed in the extreme differentiates, which correspond to melts present after extensive crystallization of plagioclase. 
Figure 13 also includes REE patterns for the four especially depleted samples (81-1-270, 81-1-273.6, 88-2-301.7, and 88-2-322.2) that were singled out in figure 11. All four have positive Eu anomalies, with that in the least depleted (81-1-273.6) sample having the smallest. Evidently this material is complementary to the segregation veins and other differentiates, supporting the idea that some of the liquid in the segregation veins originated in zones VI and VII, as proposed in Helz and Taggart (2010).

\section{Discussion and Summary}

The purpose of obtaining trace-element data on a subset of samples from Kilauea Iki lava lake was to document their behavior in a basaltic system undergoing extensive fractionation at low pressure and water activity. Earlier studies suggested that open system behavior in Kilauea Iki lava lake has been very limited. Some volatiles $\left(\mathrm{CO}_{2}\right.$, some chlorine, and much of the original $\mathrm{H}_{2} \mathrm{O}$ present in the lava) were lost during the eruption or very shortly thereafter, although in the same report Helz and others (1994) showed that there was no loss of either $\mathrm{F}$ or $\mathrm{Cl}$ from subsequent lake samples, at least from 1967 through 1981. Sulfur was lost gradually over time, with the melt degassing significant sulfur during the 1967-1976 drilling episodes, as documented in Helz and Wright (1983). One other element lost during the aging and crystallization of the lava lake is Re, as documented by Pitcher and others (2009).

The overall pattern of enrichment or depletion of individual trace elements is summarized in figure 14. In this figure, the trace-element concentrations for the three most differentiated samples analyzed from the lava lake have been normalized to the average of the following four samples: 79-3-160.5 (zone IV, MgO = 16.05 percent), 79-3-172.8 (zone IV, MgO = 18.71 percent), 79-5-260.0 (lower chill, $\mathrm{MgO}=18.84$ percent), and 79-5-300.5 (lower chill, $\mathrm{MgO}=16.61$ percent). All four samples are undifferentiated with respect to eruption samples and lie very close to the olivine-control lines shown in figures 9-11 but were not used to define those lines. Their average MgO content is 17.71 percent, somewhat higher than the average for the lava lake, which was estimated by Wright (1973) as 15.5 percent MgO. This denominator was used because there are no samples that have the lake’s average MgO content among those analyzed for trace elements. Figure 14 also includes enrichment factors for $\mathrm{K}$ and $\mathrm{P}$, for purposes of comparison with the enrichment factors for the various trace elements.

For elements shown in figure 8 plus Co, the enrichment factors rise steeply from left to right, being lowest for $\mathrm{Cr}$ (concentrated in chromite) and highest for $\mathrm{Cu}$ (concentrated in late-separating sulfide). The figure shows that Co lies between $\mathrm{Ni}$ and $\mathrm{Zn}$ in its compatibility with olivine, consistent with other studies (for example, Gunn, 1971). The next group of elements (from fig. 9) includes the few which, along with $\mathrm{Zn}$, are mildly compatible with some of the major phases (augite, plagioclase) crystallizing in the lava lake. Note that $\mathrm{Y}$, the most incompatible in this group, is distinctly less enriched than the other incompatible elements.

The remaining two groups of elements are all highly incompatible, with enrichment factors of 3.4 to 7.4. They are no more highly concentrated than $\mathrm{K}$ and $\mathrm{P}$, however, so no special processes of trace-element enrichment were active in the lava lake. In particular, there is no evidence for the "volatile transfer” process invoked by Richter and Moore (1966) to explain some erroneous analyses from the earliest (1960-1961) drill core. It should be noted that apatite has begun to crystallize in sample 79-5-163.0; this crystallization has affected its $P$ enrichment factor and may have affected the concentrations of the HFSE (other than Th and U) in this sample as well.

The results presented in this report show that, for the elements considered here, the lava lake has indeed been a closed system and that the behavior of the trace elements is completely congruent with fractionation processes inferred on the basis of major-element compositional variations. These data, 
coupled with determination of trace elements on the glasses and individual crystalline phases, may allow determination of trace-element partitioning coefficients for the principal phases in basalt over a wide range of temperatures.

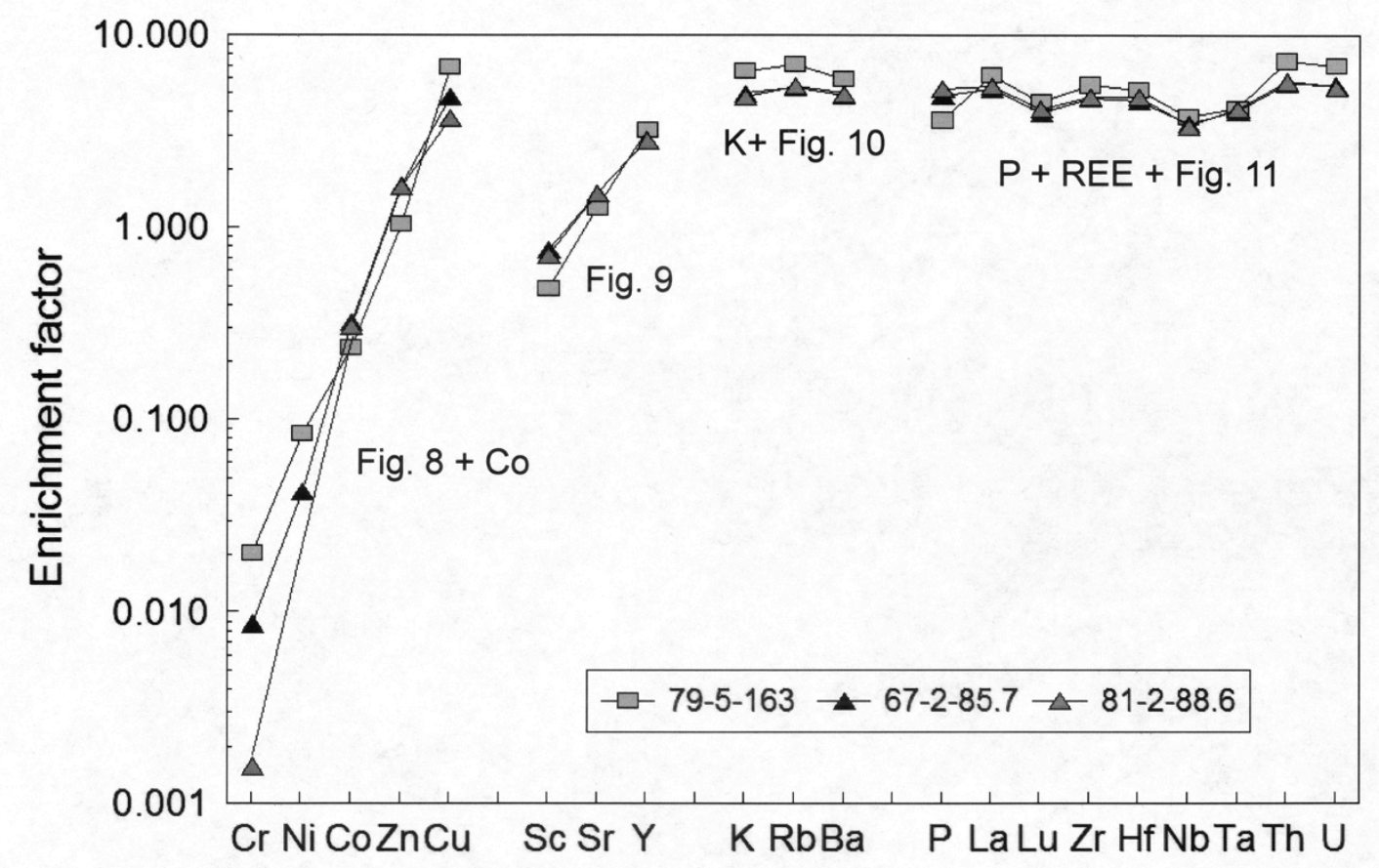

Figure 14. Enrichment factors for the three most differentiated samples from Kilauea lki lava lake, compared with the average of four undifferentiated samples with $\mathrm{MgO}=16.05$ to 18.84 weight percent. Elements shown include those from figures 8-11, plus Co, K, and P, with the REE represented by La and Lu. 


\section{References Cited}

Anders, E., and Ebihara, M., 1982, Solar-system abundances of the elements: Geochimica Cosmochimica Acta, v. 46, p. 2363-2380.

Aruscavage, P.J., and Crock, J.G., 1987, Atomic absorption methods: U.S. Geological Survey Bulletin 1770, p. C1-C6.

Baedecker, P.A., and Grossman, J.N., 1989, The computer analysis of high resolution gamma-ray spectra from instrumental activation analysis experiments: U.S. Geological Survey Open-File Report 89-454, 88 p.

Baedecker, P.A., and McKown, D.M., 1987, Instrumental neutron activation analysis of geochemical samples: U.S. Geological Survey Bulletin 1770, H1-H14.

Barth, G.A., Kleinrock, M.C., and Helz, R.T., 1994, The magma body at Kilauea Iki lava lake-Potential insights into mid-ocean ridge magma chambers: Journal of Geophysical Research, v. 99, p. 7199-7217.

Buddington, A.F., and Lindsley, D.H., 1964, Iron-titanium oxide minerals and synthetic equivalents: Journal of Petrology v. 5, p. 310-357.

Drake, M.J., 1975, The oxidation state of europium as an indicator of oxygen fugacity: Geochimica et Cosmochimica Acta, v. 39, p. 55-64.

Drake, M.J., and Weill, D.F., 1975, Partition of Sr, Ba, Ca, Y, $\mathrm{Eu}^{+2}, \mathrm{Eu}^{+3}$, and other REE between plagioclase feldspar and magmatic liquid-An experimental study: Geochimica et Cosmochimica Acta, v. 39, p. 689-712.

Grossman, J.N., and Baedecker, P.A., 1987, Interactive methods for data reduction and quality control in INAA: Journal of Radioanalytical and Nuclear Chemistry, v. 113, p. 43-59.

Gunn, B.M., 1971, Trace-element partition during olivine fractionation of Hawaiian basalts: Chemical Geology, v. 8, p. 1-13.

Helz, R.T., 1980, Crystallization history of Kilauea Iki lava lake as seen in drill core recovered in 1967-1979: Bulletin Volcanologique, v. 43-4, p. 675-701.

Helz, R.T., 1987a, Differentiation behavior of Kilauea Iki lava lake, Kilauea Volcano, Hawaii-An overview of past and current work, in Mysen, B.O., ed., Magmatic Processes_-Physicochemical Principles: Geochemical Society Special Publication 1, p. 241-258.

Helz, R.T., 1987b, Character of olivines in lavas of the 1959 eruption of Kilauea Volcano and its bearing on eruption dynamics, in Decker, R.W., Wright, T.L., and Stauffer, P.H., eds., Volcanism in Hawaii: U.S. Geological Survey Professional Paper 1350, p. 691-722.

Helz, R.T., 1993, Drilling report and core logs for the 1988 drilling of Kilauea Iki lava lake, Kilauea Volcano, Hawaii, with summary descriptions of the occurrence of foundered crust and fractures in the drill core: U.S. Geological Survey Open-File Report 93-15, 57 p.

Helz, R.T., 2009, Processes active in mafic magma chambers-The example of Kilauea Iki lava lake, Hawaii: Lithos, v. 111, p. 37-46.

Helz, R.T., and Taggart, J.E., Jr., 2010, Whole-rock analyses of core samples from the 1988 drilling of Kîlauea Iki lava lake, Hawaii: U.S. Geological Survey Open-File Report 2010-1093, 47 p. Helz, R.T., and Thornber, C.R., 1987, Geothermometry of Kilauea Iki lava lake: Bulletin of Volcanology, v. 49, p. 651-668.

Helz, R.T., and Wright, T.L., 1983, Drilling report and core logs for the 1981 drilling of Kilauea Iki lava lake (Kilauea Volcano, Hawaii), with comparative notes on earlier (1967-1979) drilling experiences: U.S. Geological Survey Open-File Report 83-326, 66 p. 
Helz, R.T., Banks, N.G., Casadevall, T.J., Fiske, R.S., and Moore, R.B., 1984, A catalogue of drill core recovered from Kilauea Iki lava lake from 1967 to 1979: U.S. Geological Survey Open-File Report 84-484, 72 p.

Helz, R.T., Kirschenbaum, H., and Marinenko, J.W., 1989, Diapiric transfer of melt in Kilauea Iki lava lake, Hawaii-A quick, efficient process of igneous differentiation: Geological Society of America Bulletin, v. 101, p. 578-594.

Helz, R.T., Kirschenbaum, H., Marinenko, J.W., and Qian, Rachel, 1994, Whole-rock analyses of core samples from the 1967, 1975, 1979 and 1981 drillings of Kilauea Iki lava lake, Hawaii:

U.S. Geological Survey Open-File Report 94-684, 65 p.

Jezek, P.A., Sinton, J.M., Jarosewich, E., and Obermeyer, C.R., 1979, Fusion of rock and mineral poweders for electron microprobe analysis: Smithsonian Contributions to the Earth Sciences, v. 22, p. 46-53.

Johnson, R.G., and King, B.-S. L., 1987, Energy-dispersive X-ray fluorescence spectrometry: U.S. Geological Survey Bulletin 1770, p. F1-F5.

Kirschenbaum, Herbert, 1983, The classical chemical analysis of silicate rocks-The old and the new: U.S. Geological Survey Bulletin 1547, 55 p.

Leeman, W.P., Budahn, J.R., Gerlach, D.C., Smith, D.R., and Powell, B.N., 1980, Origin of Hawaiian tholeiites-Trace-element constraints: American Journal of Science, v. 280-A, p. 794-819.

Lichte, F.E., Golightly, D.W., and Lamothe, P.J., 1987, Inductively coupled plasma-atomic emission spectroscopy: U.S. Geological Survey Bulletin 1770, p. B1-10.

Murata, K.J., and Richter, D.H., 1966, Chemistry of the lavas of the 1959-60 eruption of Kilauea Volcano, Hawaii: U.S. Geological Survey Professional Paper 537-A, 26 p.

Pitcher, L., Helz, R.T., Walker, R.J., and Piccoli, P., 2009, Fractionation of the platinum-group elements and Re during crystallization of basalt in Kilauea Iki lava lake, Hawaii: Chemical Geology, v. 260, p. 196-210.

Richter, D.H., and Moore, J.G., 1966, Petrology of the Kilauea Iki lava lake, Hawaii: U.S. Geological Survey Professional Paper 537-B, 26 p.

Richter, D.H., and Murata, K.J., 1966, Petrography of the lavas of the 1959-60 eruption of Kilauea Volcano, Hawaii: U.S. Geological Survey Professional Paper 537-D, 12 p.

Tilling, R.I., Wright, T.L., and Millard, H.T., Jr., 1987, Trace-element chemistry of Kîlauea and Mauna Loa lava in space and time-A reconnaissance, in Decker, R.W., Wright, T.L., and Stauffer, P.H., eds., Volcanism in Hawaii: U.S. Geological Survey Professional Paper 1350, v. 1, p. 641-690.

Wright, T.L., 1971, Chemistry of Kilauea and Mauna Loa lava in space and time. U.S. Geological Survey Professional Paper 735, 40 p.

Wright, T.L., 1973, Magma mixing as illustrated by the 1959 eruption, Kilauea Volcano, Hawaii: Geological Society of America Bulletin, v. 84, p. 849-858. 
Table A1. Instrumental neutron-activation analyses of trace elements for samples from the 1959 Kilauea lki eruption.

[Most whole-rock major-element analyses (S-numbers) are in Murata and Richter (1966). Iki-3 analysis is in Helz and

Taggart (2010). Mixing fractions are from Wright (1973). wt \%, weight percent; ppm, parts per million; nd, not determined; ${ }^{\circ} \mathrm{C}$, degrees Celsius; <, less than]

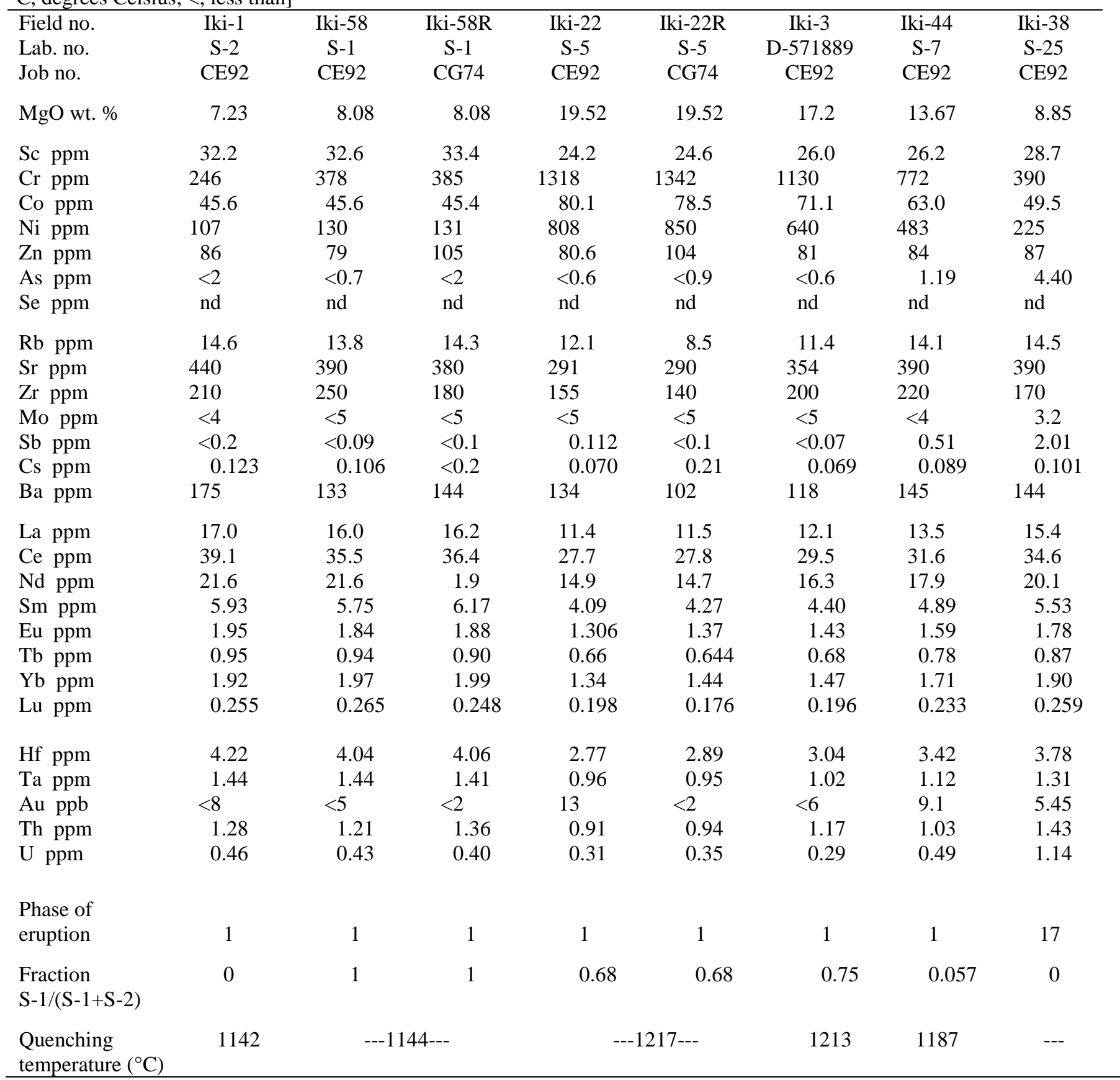


Table A2. Instrumental neutron-activation analyses of trace elements for samples from the 1967 Kilauea Iki drill core.

[Major-element analyses are in Helz and others (1994). wt \%, weight percent; ppm, parts per million; nd, not determined; $<$, less than]

\begin{tabular}{|c|c|c|c|c|c|c|c|c|}
\hline \multirow{3}{*}{$\begin{array}{l}\text { Field no. } \\
\text { Lab. no. } \\
\text { Job no. }\end{array}$} & $67-1-89.0$ & $67-2-17.0$ & 67-2-17.0R & $67-2-59.8$ & $67-2-79.9$ & $67-2-85.7$ & $67-2-89.5$ & $67-2-94.6$ \\
\hline & D-102046 & \multicolumn{2}{|c|}{ W-214299 } & W-214301 & W-214302 & D-102049 & D-102048 & D-103993 \\
\hline & CG74 & CE76 & CG74 & CE76 & CE76 & CE76 & CE76 & CE76 \\
\hline MgO (wt \%) & 4.83 & 18.26 & 18.26 & 16.53 & 22.34 & 2.60 & 13.07 & 15.91 \\
\hline Sc $\mathrm{ppm}$ & 30.5 & 24.6 & 24.2 & 25.9 & 21.7 & 20.0 & 27.3 & 27.9 \\
\hline $\mathrm{Cr} \mathrm{ppm}$ & 39.7 & 1238 & 1167 & 1125 & 1562 & 10.4 & 811 & 1128 \\
\hline Co ppm & 39.6 & 80.5 & 76.3 & 72.5 & 94.0 & 24.9 & 68.3 & 71.7 \\
\hline Ni ppm & 39 & 816 & 830 & 698 & 1090 & 32 & 491 & 602 \\
\hline Zn ppm & 142 & 102.1 & 104 & 95 & 100 & 165 & 119 & 92 \\
\hline As ppm & $<0.7$ & 1.15 & $<0.9$ & 1.6 & $<0.6$ & $<1$ & $<8$ & 1.05 \\
\hline Se ppm & nd & $<2$ & nd & $<2$ & $<0.9$ & $<2$ & $<2$ & $<0.8$ \\
\hline $\mathrm{Rb} \mathrm{ppm}$ & 20.4 & 9.3 & 9.3 & 10.5 & 10.4 & 47.0 & 14.1 & 9.6 \\
\hline Sr ppm & 399 & 391 & 315 & 440 & $<400$ & 500 & 403 & 450 \\
\hline Zr ppm & 272 & 165 & 130 & 145 & 102 & 550 & 123 & $<150$ \\
\hline Mo ppm & $<6$ & $<6$ & $<5$ & $<4$ & $<6$ & 3.8 & $<4$ & $<6$ \\
\hline Sb ppm & $<0.2$ & 0.15 & $<0.09$ & $<0.08$ & $<0.07$ & 0.28 & $<0.2$ & 0.15 \\
\hline Cs ppm & 0.24 & $<0.2$ & $<0.1$ & $<0.2$ & $<0.2$ & $<0.2$ & $<0.2$ & $<0.2$ \\
\hline Ba ppm & 246 & 111 & 101 & 117 & 101 & 503 & 156 & 93 \\
\hline La ppm & 29.0 & 11.23 & 11.0 & 12.5 & 9.7 & 61.5 & 16.0 & 10.8 \\
\hline Ce ppm & 65.7 & 27.0 & 27.0 & 30.3 & 24.6 & 137.5 & 37.1 & 26.1 \\
\hline Nd ppm & 36.5 & 14.9 & 14.6 & 15.4 & 12.3 & 78.4 & 20.4 & 14.8 \\
\hline Sm ppm & 10.38 & 4.21 & 4.17 & 4.71 & 3.61 & 19.6 & 5.86 & 4.16 \\
\hline Eu ppm & 3.05 & 1.326 & 1.34 & 1.50 & 1.12 & 5.41 & 1.81 & 1.36 \\
\hline $\mathrm{Tb} \mathrm{ppm}$ & 1.46 & 0.648 & 0.637 & 0.70 & 0.54 & 2.63 & 0.895 & 0.68 \\
\hline $\mathrm{Yb} \mathrm{ppm}$ & 3.20 & 1.38 & 1.44 & 1.53 & 1.12 & 5.89 & 1.90 & 1.35 \\
\hline Lu ppm & 0.415 & 0.186 & 0.184 & 0.204 & 0.165 & 0.769 & 0.242 & 0.188 \\
\hline Hf ppm & 7.02 & 2.88 & 2.77 & 3.20 & 2.41 & 13.69 & 4.09 & 2.76 \\
\hline Ta ppm & 2.45 & 0.973 & 0.96 & 1.07 & 0.775 & 4.04 & 1.35 & 0.85 \\
\hline $\mathrm{Au} \mathrm{ppb}$ & $<9$ & $<6$ & $<0.7$ & $<6$ & $<3$ & $<7$ & $<9$ & $<1$ \\
\hline Th ppm & 2.32 & 0.92 & 0.88 & 0.96 & 0.69 & 5.19 & 1.35 & 0.88 \\
\hline U ppm & 0.54 & 0.22 & 0.21 & 0.40 & 0.22 & 1.54 & 0.40 & 0.25 \\
\hline $\begin{array}{l}\text { Type of } \\
\text { sample }\end{array}$ & $\begin{array}{l}\text { glass } \\
\text { in bit }\end{array}$ & (I) & (I) & $\begin{array}{l}\text { foundered } \\
\text { crust }\end{array}$ & $\begin{array}{c}\text { foundered } \\
\text { crust }\end{array}$ & ooze & $\begin{array}{l}\text { leopard } \\
\text { rock }\end{array}$ & $\begin{array}{l}\text { foundered } \\
\text { crust }\end{array}$ \\
\hline $\begin{array}{l}\text { Contains } \\
\text { glass? }\end{array}$ & yes & no & no & yes & yes & yes & yes & yes \\
\hline $\begin{array}{l}\text { Quenching } \\
\text { temperature }\end{array}$ & high & low & low & medium & high & high & high & high \\
\hline
\end{tabular}


Table A2. Instrumental neutron-activation analyses of trace elements for samples from the 1967 Kilauea Iki drill core.-Continued

\begin{tabular}{|c|c|c|c|c|c|c|c|}
\hline \multirow{3}{*}{$\begin{array}{l}\text { Field no. } \\
\text { Lab. no. } \\
\text { Job no. }\end{array}$} & \multirow{3}{*}{$\begin{array}{c}\text { 67-3-6.8 } \\
\text { W-214121 } \\
\text { CD53 }\end{array}$} & $67-3-27.5$ & 67-3-27.5R & \multirow{3}{*}{$\begin{array}{c}\text { 67-3-39.0 } \\
\text { D-103977 } \\
\text { CD53 }\end{array}$} & \multirow{3}{*}{$\begin{array}{c}67-3-47.8 \\
\text { D-103978 } \\
\text { CD53 }\end{array}$} & \multirow{3}{*}{$\begin{array}{c}\text { 67-3-58.0 } \\
\text { D-103979 } \\
\text { CE76 }\end{array}$} & \multirow{3}{*}{$\begin{array}{c}\text { 67-3-87.0 } \\
\text { D-102054 } \\
\text { CG74 }\end{array}$} \\
\hline & & \multicolumn{2}{|c|}{ D-103976 } & & & & \\
\hline & & CE76 & CG74 & & & & \\
\hline $\mathrm{MgO}$ wt \% & 25.83 & 12.01 & 12.01 & 10.73 & 13.10 & 8.91 & 5.44 \\
\hline Sc ppm & 19.58 & 30.89 & 30.0 & 31.4 & 29.0 & 30.7 & 31.0 \\
\hline Cr ppm & 1630 & 773 & 739 & 670 & 819 & 516 & 40.4 \\
\hline Co ppm & 104.4 & 60.6 & 57.3 & 56.9 & 65.0 & 47.4 & 39.9 \\
\hline i ppm & 1327 & 389 & 386 & 327 & 485 & 223 & 89 \\
\hline Zn ppm & 96.4 & 103.7 & 103 & 106 & 109 & 107 & 140 \\
\hline As ppm & $<0.9$ & 1.4 & $<1$ & $<1$ & $<0.6$ & 1.9 & $<0.8$ \\
\hline Se ppm & $<3$ & $<2$ & nd & $<3$ & $<2$ & $<2$ & nd \\
\hline $\mathrm{Rb}$ ppm & 8.5 & 10.5 & 13.3 & 12.0 & 12.2 & 16.5 & 23.0 \\
\hline Sr ppm & $<400$ & 418 & 366 & 406 & 370 & 448 & 420 \\
\hline Zr ppm & 118 & 180 & $<130$ & 200 & 153 & 180 & 230 \\
\hline Mo ppm & $<6$ & $<6$ & $<6$ & $<8$ & $<5$ & $<5$ & $<5$ \\
\hline Sb ppm & $<0.09$ & $<0.1$ & $<0.1$ & 0.19 & $<0.07$ & 0.15 & $<0.2$ \\
\hline Cs ppm & $<0.2$ & $<0.2$ & $<0.3$ & $<0.3$ & $<0.2$ & $<0.2$ & 0.27 \\
\hline Ba ppm & 94 & 142 & 114 & 138 & 141 & 156 & 244 \\
\hline La ppm & 8.56 & 14.4 & 14.0 & 15.6 & 15.21 & 18.1 & 27.9 \\
\hline Ce ppm & 22.1 & 34.0 & 33.5 & 36.8 & 36.3 & 41.4 & 62.8 \\
\hline $\mathrm{Nd} \mathrm{ppm}$ & 11.2 & 20.0 & 18.4 & 21.2 & 21.6 & 23.4 & 36.3 \\
\hline Sm ppm & 3.20 & 5.41 & 5.41 & 5.83 & 5.69 & 6.58 & 10.0 \\
\hline Eu ppm & 1.010 & 1.73 & 1.71 & 1.83 & 1.81 & 2.11 & 2.97 \\
\hline Tb ppm & 0.489 & 0.802 & 0.79 & 0.876 & 0.84 & 0.99 & 1.41 \\
\hline $\mathrm{Yb} \mathrm{ppm}$ & 1.07 & 1.77 & 1.80 & 1.86 & 1.79 & 2.18 & 3.18 \\
\hline Lu ppm & 0.145 & 0.235 & 0.218 & 0.256 & 0.253 & 0.292 & 0.393 \\
\hline Hf ppm & 2.16 & 3.65 & 3.63 & 3.90 & 3.85 & 4.61 & 6.92 \\
\hline Та ppm & 0.739 & 1.22 & 1.18 & 1.31 & 1.30 & 1.61 & 2.34 \\
\hline $\mathrm{Au} \mathrm{ppb}$ & $<5$ & $<9$ & $<1$ & 7.6 & $<5$ & $<6$ & $<4$ \\
\hline Th ppm & 0.67 & 1.07 & 1.19 & 1.21 & 1.28 & 1.47 & 2.23 \\
\hline $\mathrm{U}$ ppm & 0.24 & 0.30 & 0.41 & 0.42 & 0.38 & 0.44 & 0.63 \\
\hline $\begin{array}{l}\text { Type of } \\
\text { sample }\end{array}$ & (I) & (I) & (I) & (I) & (II) & (II) & $\begin{array}{l}\text { glass } \\
\text { in bit }\end{array}$ \\
\hline $\begin{array}{l}\text { Contains } \\
\text { glass? }\end{array}$ & no & no & no & no & no & yes & \\
\hline $\begin{array}{l}\text { Quenching } \\
\text { temperature }\end{array}$ & low & low & low & low & medium & medium & high \\
\hline
\end{tabular}


Table A3. Instrumental neutron-activation analyses of trace elements for samples from the 1975 Kilauea Iki drill core.

[Major-element analyses are in Helz and others (1994). wt \%, weight percent; ppm, parts per million; <, less than]

\begin{tabular}{|c|c|c|c|c|c|c|c|c|}
\hline Field no. & $75-1-60.9$ & $75-1-75.2$ & $75-1-85.5$ & $75-1-95.0$ & $75-1-110$ & \multirow{2}{*}{\multicolumn{2}{|c|}{$\begin{array}{c}\text { 75-1-114.9 } \\
\text { D-103853 }\end{array}$}} & $75-1-121.5$ \\
\hline Lab. no. & D-103844 & D-103846 & D-103848 & D-103850 & D-103852 & & & D-103855 \\
\hline & & & & & & $\mathrm{a}$ & $\mathrm{b}$ & \\
\hline Job no. & CD53 & CD53 & CD53 & CE76 & CE76 & CE76 & CE76 & CD53 \\
\hline MgO wt \% & 10.52 & 5.77 & 8.33 & 9.64 & 8.27 & 5.26 & 5.26 & 7.77 \\
\hline Sc $\mathrm{ppm}$ & 30.6 & 32.8 & 32.2 & 31.4 & 31.1 & 31.1 & 30.3 & 31.9 \\
\hline Cr ppm & 674 & 50.1 & 515 & 630 & 504 & 20.2 & 19.9 & 479 \\
\hline Co ppm & 53.3 & 40.9 & 45.5 & 50.7 & 44.9 & 42.7 & 42.1 & 43.6 \\
\hline $\mathrm{Ni} \mathrm{ppm}$ & 331 & 91 & 229 & 257 & 199 & 63 & 72 & 169 \\
\hline $\mathrm{Zn} \mathrm{ppm}$ & 103 & 126 & 107 & 102.9 & 106 & 137 & 133 & 109 \\
\hline As ppm & $<0.8$ & $<1$ & $<0.6$ & $<0.6$ & $<0.9$ & $<1$ & $<1$ & $<0.9$ \\
\hline Se ppm & $<2$ & $<2$ & $<3$ & $<0.8$ & $<2$ & $<3$ & $<3$ & $<3$ \\
\hline $\mathrm{Rb}$ ppm & 15.8 & 18.8 & 12.4 & 13.8 & 13.9 & 23.0 & 23 & 17.9 \\
\hline Sr ppm & 440 & 506 & 460 & 470 & 426 & 510 & 510 & 440 \\
\hline $\mathrm{Zr}$ ppm & 157 & 229 & 196 & 117 & 190 & 290 & 310 & 174 \\
\hline Mo ppm & $<5$ & 3.1 & $<4$ & $<5$ & $<6$ & $<4$ & 2.8 & $<3$ \\
\hline $\mathrm{Sb} \mathrm{ppm}$ & 0.149 & $<0.1$ & 0.096 & $<0.2$ & $<0.09$ & $<0.1$ & 0.17 & $<0.09$ \\
\hline Cs ppm & 0.281 & $<0.3$ & $<0.2$ & 0.26 & 0.380 & 0.36 & $<0.2$ & $<0.2$ \\
\hline $\mathrm{Ba}$ ppm & 167 & 207 & 165 & 151 & 170 & 263 & 244 & 190 \\
\hline La ppm & 16.7 & 23.3 & 17.7 & 15.8 & 17.9 & 28.3 & 28.1 & 19.0 \\
\hline Ce ppm & 39.8 & 52.7 & 42.2 & 36.7 & 41.7 & 64.0 & 64.2 & 44.3 \\
\hline Nd ppm & 23.2 & 31.6 & 24.2 & 22.4 & 23.4 & 37.7 & 36.5 & 26.4 \\
\hline Sm ppm & 6.17 & 8.26 & 6.61 & 5.98 & 6.60 & 9.91 & 9.63 & 6.94 \\
\hline Eu ppm & 1.92 & 2.63 & 2.07 & 1.89 & 2.07 & 3.05 & 2.95 & 2.21 \\
\hline $\mathrm{Tb} \mathrm{ppm}$ & 0.88 & 1.21 & 0.96 & 0.92 & 0.98 & 1.38 & 1.39 & 1.016 \\
\hline $\mathrm{Yb} \mathrm{ppm}$ & 2.00 & 2.63 & 2.16 & 2.07 & 2.22 & 3.20 & 3.15 & 2.22 \\
\hline Lu ppm & 0.272 & 0.364 & 0.282 & 0.261 & 0.295 & 0.427 & 0.417 & 0.306 \\
\hline Hf ppm & 4.27 & 6.00 & 4.57 & 4.15 & 4.64 & 7.33 & 7.27 & 4.97 \\
\hline Ta ppm & 1.48 & 2.13 & 1.57 & 1.39 & 1.55 & 2.55 & 2.52 & 1.67 \\
\hline $\mathrm{Au} \mathrm{ppb}$ & $<5$ & $<3$ & $<3$ & $<6$ & $<2$ & $<9$ & $<6$ & $<4$ \\
\hline Th ppm & 1.35 & 1.92 & 1.46 & 1.30 & 1.43 & 2.40 & 2.41 & 1.52 \\
\hline $\mathrm{U}$ ppm & 0.36 & 0.58 & 0.39 & 0.25 & 0.48 & 0.71 & $<0.9$ & 0.42 \\
\hline $\begin{array}{l}\text { Type of } \\
\text { sample }\end{array}$ & (II) & $\begin{array}{l}\text { segregation } \\
\text { vein }\end{array}$ & (II) & (II) & (II) & segr & tion & (II) \\
\hline $\begin{array}{l}\text { Contains } \\
\text { glass? }\end{array}$ & no & no & no & no & no & ---- & ---- & no \\
\hline $\begin{array}{l}\text { Quenching } \\
\text { temperature }\end{array}$ & low & low & low & low & medium & & & medium \\
\hline
\end{tabular}


Table A3. Instrumental neutron-activation analyses of trace elements for samples from the 1975 Kilauea Iki drill core.-Continued

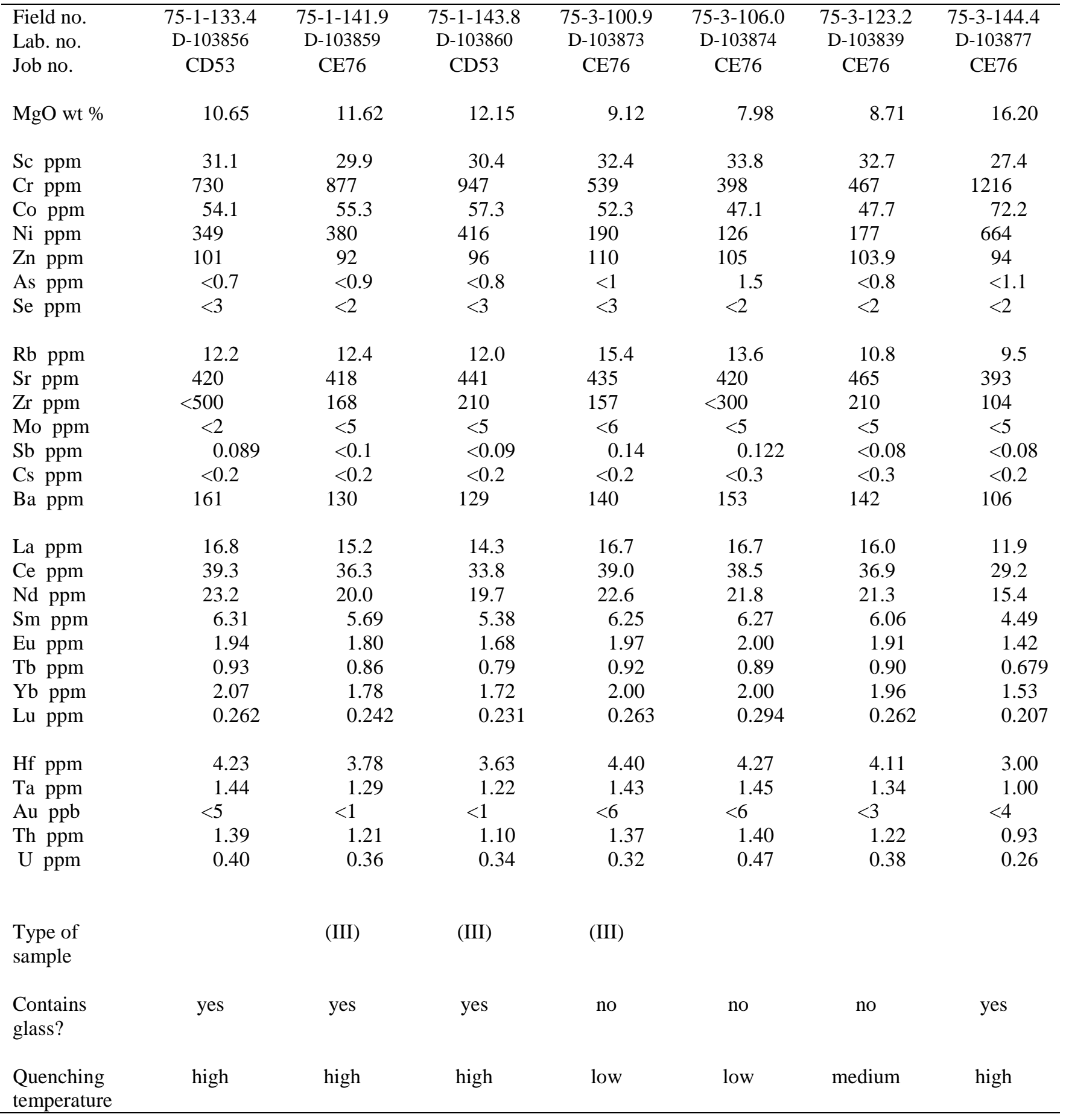


Table A4. Instrumental neutron-activation analyses of trace elements for samples from the 1979 Kilauea Iki drill core.

[Most major-element analyses are in Helz and others (1994). wt \%, weight percent; ppm, parts per million; nd, not determined; <, less than]

\begin{tabular}{|c|c|c|c|c|c|c|c|c|}
\hline $\begin{array}{l}\text { Field no. } \\
\text { Lab. no. } \\
\text { Job no. }\end{array}$ & $\begin{array}{c}\text { 79-1R1-167.8 } \\
\text { W-235378 } \\
\text { CG74 }\end{array}$ & $\begin{array}{c}\text { 79-1R1-170.8 } \\
\text { W-235379 } \\
\text { CG74 }\end{array}$ & $\begin{array}{c}\text { 79-3-145.1 } \\
\text { W-210495 } \\
\text { CD53 }\end{array}$ & $\begin{array}{c}\text { 79-3-150.4 } \\
\text { W-210496 } \\
\text { CD53 }\end{array}$ & $\begin{array}{c}\text { 79-3-158.0 } \\
\text { W-214317 } \\
\text { CD53 }\end{array}$ & $\begin{array}{c}79-3-160.3 \\
\text { W-210497 } \\
\text { CE76 }\end{array}$ & $\begin{array}{c}\text { 79-3-172.8 } \\
\text { W-210500 } \\
\text { CD53 }\end{array}$ & $\begin{array}{c}\text { 79-3R2-168 } \\
\text { W-235391 } \\
\text { CG74 }\end{array}$ \\
\hline MgO wt \% & 3.42 & 3.48 & 26.16 & 13.51 & 4.5 & 16.05 & 18.71 & 5.07 \\
\hline Sc $\mathrm{ppm}$ & 21.6 & 22.0 & 19.4 & 30.6 & 28.8 & 27.19 & 26.2 & 30.1 \\
\hline Cr ppm & 9.3 & 8.8 & 1280 & 1108 & 28.6 & 1086 & 1300 & 37.8 \\
\hline Co ppm & 26.4 & 27.5 & 114.4 & 61.8 & 35.0 & 73.2 & 81.7 & 36.9 \\
\hline $\mathrm{Ni}$ ppm & 20 & 33 & 1280 & 507 & 64 & 684 & 814 & 79 \\
\hline $\mathrm{Zn} \mathrm{ppm}$ & 150 & 152 & 111 & 97 & 133 & 100 & 102 & 138 \\
\hline As ppm & $<3$ & $<2$ & $<0.6$ & $<4$ & $<0.8$ & $<1$ & $<0.6$ & 1.16 \\
\hline Se ppm & nd & nd & $<2$ & $<2$ & $<3$ & $<3$ & $<2$ & nd \\
\hline $\mathrm{Rb} \mathrm{ppm}$ & 36.0 & 35.1 & $<8$ & 8.9 & 27.2 & 8.8 & 8.2 & 24.7 \\
\hline Sr ppm & 435 & 493 & $<400$ & 410 & 510 & 374 & 290 & 441 \\
\hline $\mathrm{Zr} \mathrm{ppm}$ & 430 & 401 & $<140$ & 170 & 330 & 160 & $<160$ & 276 \\
\hline Mo ppm & 4.6 & $<4$ & $<2$ & $<4$ & 3.9 & $<5$ & $<6$ & $<4$ \\
\hline Sb ppm & 0.49 & 0.19 & $<0.06$ & 0.145 & 0.088 & $<0.1$ & $<0.07$ & 0.17 \\
\hline Cs ppm & 0.313 & 0.36 & $<0.2$ & $<0.2$ & $<0.2$ & $<0.2$ & $<0.2$ & $<0.3$ \\
\hline $\mathrm{Ba} \mathrm{ppm}$ & 389 & 395 & 68 & 122 & 331 & 117 & 88 & 248 \\
\hline La ppm & 50.1 & 50.3 & 6.55 & 12.6 & 37.3 & 12.4 & 10.42 & 30.8 \\
\hline Ce ppm & 112.1 & 110.2 & 17.7 & 31.4 & 84.1 & 30.1 & 26.8 & 9.9 \\
\hline $\mathrm{Nd} \mathrm{ppm}$ & 61.1 & 58.4 & 8.7 & 18.1 & 48.8 & 17.3 & 14.9 & 40.2 \\
\hline Sm ppm & 16.7 & 16.3 & 2.53 & 4.84 & 12.2 & 4.74 & 4.01 & 11.04 \\
\hline Eu ppm & 4.66 & 4.60 & 0.86 & 1.54 & 3.69 & 1.468 & 1.32 & 3.24 \\
\hline $\mathrm{Tb} \mathrm{ppm}$ & 2.24 & 2.23 & 0.41 & 0.72 & 1.77 & 0.705 & 0.58 & 1.55 \\
\hline $\mathrm{Yb} \mathrm{ppm}$ & 4.89 & 4.78 & 0.88 & 1.59 & 3.96 & 1.54 & 1.33 & 3.41 \\
\hline Lu ppm & 0.64 & 0.63 & 0.123 & 0.220 & 0.540 & 0.197 & 0.190 & 0.43 \\
\hline Hf ppm & 11.31 & 11.24 & 1.83 & 3.36 & 9.07 & 3.25 & 2.69 & 7.59 \\
\hline Ta ppm & 3.49 & 3.53 & 0.64 & 1.12 & 2.95 & 1.09 & 0.89 & 2.63 \\
\hline $\mathrm{Au} \mathrm{ppb}$ & $<9$ & $<11$ & $<4$ & $<7$ & $<6$ & $<12$ & 11.4 & 34 \\
\hline Th ppm & 4.12 & 4.02 & 0.49 & 1.01 & 3.20 & 0.99 & 0.84 & 2.50 \\
\hline $\mathrm{U}$ ppm & 1.16 & 1.11 & 0.19 & 0.35 & 0.84 & 0.27 & 0.26 & 0.71 \\
\hline $\begin{array}{l}\text { Type of } \\
\text { sample }\end{array}$ & ooze & ooze & vorb & (III) & $\begin{array}{l}\text { segregation } \\
\text { vein }\end{array}$ & (IV) & (IV) & ooze \\
\hline $\begin{array}{l}\text { Contains } \\
\text { glass? }\end{array}$ & yes & yes & trace? & no & yes & yes & yes & yes? \\
\hline $\begin{array}{l}\text { Quenching } \\
\text { temperature }\end{array}$ & high & high & medium & medium & high & high & high & medium \\
\hline
\end{tabular}


Table A4. Instrumental neutron-activation analyses of trace elements for samples from the 1979 Kilauea lki drill core.-Continued

\begin{tabular}{|c|c|c|c|c|c|c|c|c|c|}
\hline Field no. & $79-5$ & 160.0 & $79-5-163$ & 79-5-180.5 & $79-5-200.0$ & $79-5-240.0$ & $79-5-260.0$ & 79-5-300.5 & 79-5-313.5 \\
\hline Lab. no. & $\mathrm{W}-2$ & 4304 & --------- & W-214305 & W-214306 & W-214308 & W-214309 & W-214311 & W-214313 \\
\hline & $\mathrm{a}$ & b & & & & & & & \\
\hline Job no. & CE76 & CE76 & CE76 & CE76 & CE76 & CE76 & CD53 & CE76 & CE76 \\
\hline MgO (wt \%) & 22.08 & 22.08 & 2.57 & 20.7 & 21.30 & 20.35 & 18.84 & 16.61 & 9.51 \\
\hline Sc ppm & 23.9 & 23.6 & 12.5 & 24.8 & 23.1 & 24.8 & 25.3 & 26.5 & 32.7 \\
\hline Cr ppm & 1560 & 1573 & 24.3 & 1610 & 1491 & 1455 & 1220 & 1216 & 555 \\
\hline Co ppm & 93.6 & 93.2 & 18.3 & 87.0 & 90.8 & 88.9 & 81.7 & 74.2 & 53.3 \\
\hline $\mathrm{Ni}$ ppm & 1007 & 986 & 65 & 915 & 965 & 923 & 854 & 706 & 226 \\
\hline $\mathrm{Zn} \mathrm{ppm}$ & 100 & 96 & 104 & 98 & 99 & 105 & 99 & 100 & 111 \\
\hline As ppm & $<1$ & 0.94 & 2.5 & $<0.8$ & 1.2 & $<0.9$ & $<0.7$ & 1.8 & $<2$ \\
\hline Se $\mathrm{ppm}$ & $<3$ & $<0.8$ & 2.1 & $<3$ & $<3$ & $<3$ & $<1$ & $<2$ & $<5$ \\
\hline $\mathrm{Rb}$ ppm & 9.1 & 10.9 & 62.0 & 8.3 & 10.3 & $<6$ & 7.4 & 10.8 & 11.6 \\
\hline Sr ppm & $<400$ & 398 & $<400$ & $<400$ & $<400$ & 438 & 406 & 450 & $<400$ \\
\hline $\mathrm{Zr} \mathrm{ppm}$ & $<200$ & 670 & 119 & $<220$ & 132 & 118 & 130 & 230 & $<210$ \\
\hline Mo ppm & $<6$ & $<5$ & 5.8 & $<7$ & $<3$ & $<6$ & 2.2 & 4.7 & 2.1 \\
\hline Sb ppm & $<0.1$ & $<0.08$ & 0.27 & $<0.09$ & 0.130 & $<0.1$ & $<0.08$ & 0.10 & $<0.1$ \\
\hline Cs ppm & $<0.3$ & $<0.2$ & 0.58 & $<0.2$ & $<0.2$ & $<0.2$ & $<0.2$ & 0.36 & $<0.3$ \\
\hline Ва ppm & 74 & 97 & 614 & 81 & 83 & 88 & 110 & 102 & 155 \\
\hline La ppm & 8.4 & 8.5 & 72.4 & 9.19 & 8.99 & 8.98 & 11.7 & 12.6 & 15.5 \\
\hline Ce ppm & 22.6 & 21.3 & 161 & 23.0 & 23.4 & 22.11 & 29.5 & 29.9 & 36.4 \\
\hline $\mathrm{Nd}$ ppm & 11.8 & 12.1 & 89.0 & 11.8 & 11.6 & 14.0 & 15.4 & 14.7 & 21.7 \\
\hline Sm ppm & 3.27 & 3.26 & 21.7 & 3.53 & 3.42 & 3.48 & 4.36 & 4.68 & 5.85 \\
\hline Eu ppm & 1.034 & 1.03 & 5.51 & 1.15 & 1.12 & 1.17 & 1.39 & 1.46 & 1.84 \\
\hline $\mathrm{Tb} \mathrm{ppm}$ & 0.505 & 0.499 & 2.87 & 0.54 & 0.518 & 0.52 & 0.662 & 0.76 & 0.84 \\
\hline $\mathrm{Yb}$ ppm & 1.07 & 1.12 & 6.67 & 1.21 & 1.15 & 1.23 & 1.46 & 1.59 & 1.91 \\
\hline Lu ppm & 0.142 & 0.142 & 0.880 & 0.159 & 0.150 & 0.156 & 0.194 & 0.205 & 0.264 \\
\hline Hf ppm & 2.13 & 2.10 & 15.64 & 2.32 & 2.40 & 2.34 & 3.00 & 3.16 & 3.94 \\
\hline Ta ppm & 0.69 & 0.70 & 4.18 & 0.769 & 0.768 & 0.82 & 1.00 & 1.05 & 1.35 \\
\hline Au ppb & 5.3 & $<3$ & 4.80 & 0.74 & 0.77 & 0.66 & 0.94 & 0.92 & 1.22 \\
\hline $\mathrm{U}$ ppm & $<0.4$ & 0.22 & 1.96 & $<0.4$ & 0.23 & $<0.4$ & 0.31 & 0.72 & 0.38 \\
\hline $\begin{array}{l}\text { Type of } \\
\text { sample }\end{array}$ & & & $\begin{array}{l}\text { thin } \\
\text { vein }\end{array}$ & & & & chill & chill & chill \\
\hline $\begin{array}{l}\text { Contains } \\
\text { glass? }\end{array}$ & & o--- & yes & trace & trace & no & no & no & no \\
\hline $\begin{array}{l}\text { Quenching } \\
\text { temperature }\end{array}$ & & lium & high & high & high & medium & medium & medium & medium \\
\hline
\end{tabular}


Table A5. Instrumental neutron-activation analyses of trace elements from the 1981 Kilauea lki drill core.

\begin{tabular}{|c|c|c|c|c|c|c|c|c|}
\hline Field no. & $81-1-117.8$ & 81-1-119.2 & 81-1-119.2R & $81-1-120.3$ & $81-1-169.9$ & 81-1-190.1 & $81-1-200.4$ & $81-1-210.0$ \\
\hline Lab. no. & W-239453 & \multicolumn{2}{|c|}{ W-239454 } & W-239455 & W-214102 & W-214104 & W-214105 & W-214106 \\
\hline Job no. & CG74 & CE92 & CG74 & CE92 & CD53 & CD53 & CE76 & CE76 \\
\hline MgO (wt \%) & 4.86 & 6.74 & 6.74 & 6.95 & 26.87 & 21.91 & 25.96 & 24.53 \\
\hline Sc ppm & 30.5 & 30.1 & 31.3 & 30.3 & 18.3 & 23.4 & 19.4 & 22.1 \\
\hline Cr ppm & 11.0 & 320 & 332 & 370 & 1252 & 1468 & 1474 & 1700 \\
\hline Co ppm & 40.5 & 38.5 & 38.5 & 39.5 & 119.9 & 94.2 & 112.6 & 103.4 \\
\hline Ni ppm & 62 & 143 & 139 & 140 & 1290 & 1001 & 1260 & 1150 \\
\hline Zn ppm & 144 & 82.7 & 105 & 86 & 118 & 105 & 110 & 99 \\
\hline As ppm & $<2$ & $<0.7$ & $<1$ & 1.4 & $<0.8$ & $<0.6$ & 1.02 & $<0.9$ \\
\hline Se ppm & nd & nd & nd & nd & $<2$ & $<0.9$ & $<0.9$ & $<0.9$ \\
\hline $\mathrm{Rb} \mathrm{ppm}$ & 22.6 & 16.2 & 14.3 & 15.7 & 7.1 & 11.4 & 10.8 & $<6.0$ \\
\hline Sr ppm & 432 & 484 & 442 & 450 & 260 & 289 & $<400$ & $<500$ \\
\hline $\mathrm{Zr}$ ppm & 266 & $<400$ & 163 & 204 & $<150$ & 141 & $<200$ & $<200$ \\
\hline Mo ppm & $<7$ & $<5$ & 3.8 & 3.4 & $<6$ & $<6$ & $<7$ & $<7$ \\
\hline Sb ppm & $<0.2$ & $<0.08$ & 0.24 & 0.14 & $<0.08$ & $<0.07$ & 0.409 & $<0.2$ \\
\hline Cs ppm & 0.23 & $<0.2$ & $<0.2$ & $<0.2$ & $<0.3$ & $<0.2$ & $<0.2$ & $<0.2$ \\
\hline Ва ppm & 290 & 163 & 185 & 159 & 77 & 88 & 74 & 61 \\
\hline La ppm & 29.3 & 19.3 & 20.1 & 18.8 & 8.0 & 9.1 & 8.48 & 6.6 \\
\hline Ce ppm & 65.3 & 43.4 & 45.3 & 41.7 & 20.4 & 22.3 & 20.8 & 16.3 \\
\hline Nd ppm & 37.1 & 25.1 & 26.2 & 24.3 & 11.0 & 11.9 & 12.6 & 9.3 \\
\hline Sm ppm & 10.30 & 6.81 & 7.43 & 6.62 & 2.94 & 3.45 & 3.12 & 2.57 \\
\hline Eu ppm & 3.10 & 2.20 & 2.26 & 2.17 & 0.91 & 1.10 & 0.99 & 0.850 \\
\hline $\mathrm{Tb} \mathrm{ppm}$ & 1.46 & 1.08 & 1.043 & 1.029 & 0.443 & 0.535 & 0.44 & 0.418 \\
\hline Yb ppm & 3.30 & 2.35 & 2.40 & 2.22 & 1.06 & 1.13 & 1.05 & 0.85 \\
\hline Lu ppm & 0.431 & 0.310 & 0.305 & 0.298 & 0.130 & 0.147 & 0.147 & 0.118 \\
\hline Hf ppm & 7.42 & 4.88 & 5.02 & 4.65 & 2.04 & 2.23 & 2.13 & 1.69 \\
\hline Ta ppm & 2.64 & 1.68 & 1.73 & 1.60 & 0.71 & 0.788 & 0.67 & 0.522 \\
\hline $\mathrm{Au} \mathrm{ppb}$ & $<9$ & $<5$ & $<3$ & $<5$ & $<1$ & $<5$ & $<6$ & 6.6 \\
\hline Th ppm & 2.41 & 1.63 & 1.69 & 1.47 & 0.60 & 0.71 & 0.77 & 0.53 \\
\hline U ppm & 0.65 & 0.40 & 0.38 & 0.52 & 0.26 & 0.29 & $<0.3$ & 0.23 \\
\hline $\begin{array}{l}\text { Type of } \\
\text { sample }\end{array}$ & (II) & (II) & (II) & (II) & vorb & (V) & ogb & (V) \\
\hline $\begin{array}{l}\text { Contains } \\
\text { glass? }\end{array}$ & no & no & no & no & yes & yes & yes & yes \\
\hline $\begin{array}{l}\text { Quenching } \\
\text { temperature }\end{array}$ & low & low & low & low & high & high & high & high \\
\hline
\end{tabular}


Table A5. Instrumental neutron-activation analyses of trace elements from the 1981 Kilauea lki drill core.Continued

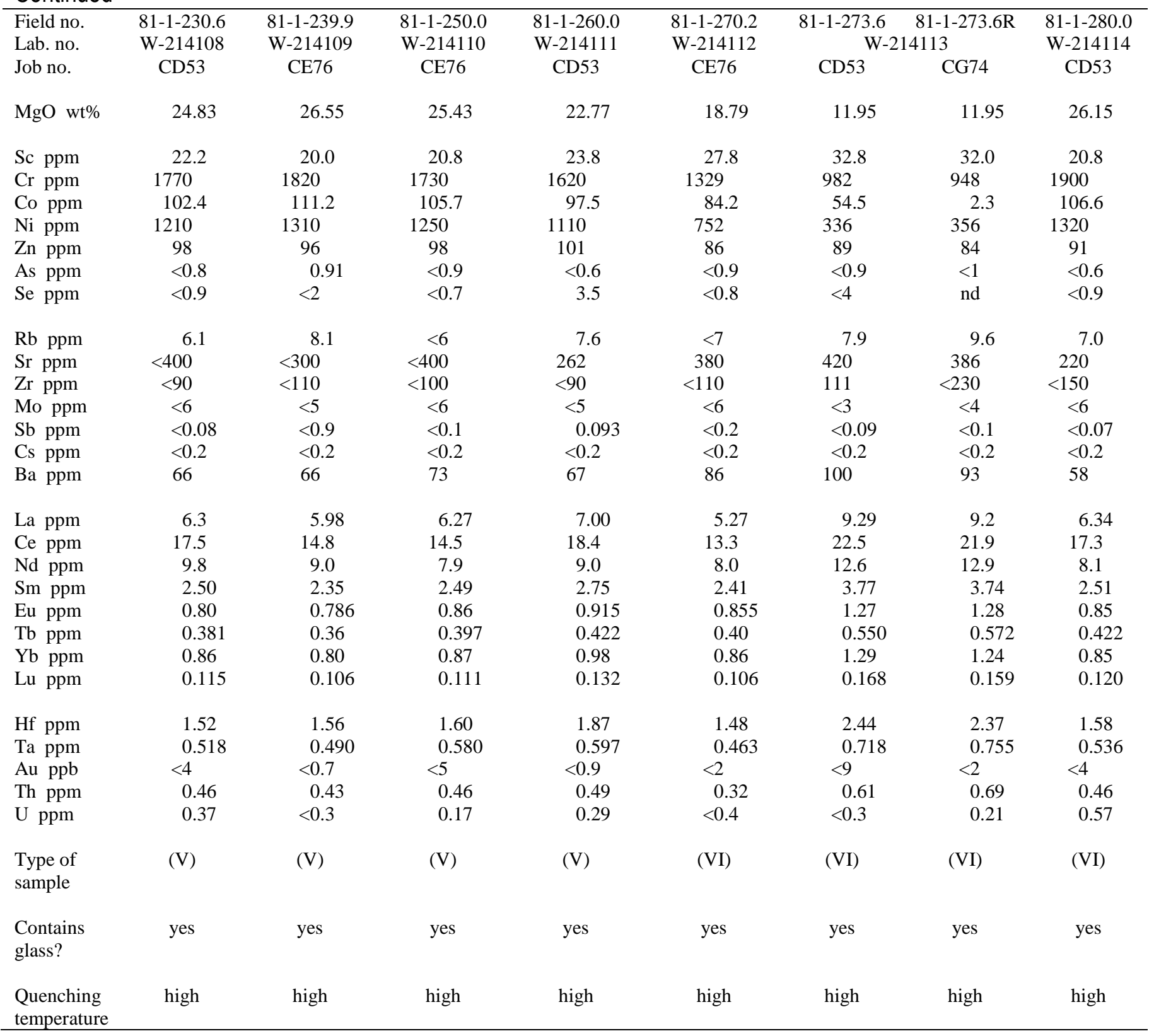


Table A5. Instrumental neutron-activation analyses of trace elements from the 1981 Kilauea Iki drill core.-Continued

\begin{tabular}{|c|c|c|c|c|c|c|}
\hline Field no. & 81-1-281.6 & 81-1-289.3 & $81-1-297.9$ & $81-1-300.2$ & $81-1-306.7$ & $81-2-88.6$ \\
\hline Lab. no. & W-214115 & W-214116 & W-214118 & W-214119 & W-214120 & W-232725 \\
\hline Job no. & CD53 & CE76 & CE76 & CD53 & CD53 & CD53 \\
\hline MgO wt \% & 18.74 & 25.58 & 15.64 & 18.15 & 17.47 & 2.37 \\
\hline Sc ppm & 25.7 & 19.5 & 27.0 & 25.7 & 26.4 & 18.8 \\
\hline $\mathrm{Cr}$ ppm & 1329 & 1581 & 1102 & 1133 & 1150 & 1.9 \\
\hline Co ppm & 83.9 & 107.2 & 71.0 & 81.5 & 78.7 & 23.6 \\
\hline $\mathrm{Ni} \mathrm{ppm}$ & 832 & 1270 & 628 & 801 & 729 & $<30$ \\
\hline Zn ppm & 104 & 102 & 94 & 104 & 99 & 164 \\
\hline As ppm & $<0.9$ & 0.85 & $<1$ & $<0.7$ & $<1.1$ & 1.73 \\
\hline Se $\mathrm{ppm}$ & $<1.8$ & $<0.7$ & $<2.9$ & $<3.2$ & $<0.9$ & $<4$ \\
\hline $\mathrm{Rb}$ ppm & 7.1 & 9.1 & 11.4 & 8.2 & 9.3 & 48.1 \\
\hline $\mathrm{Sr}$ ppm & 320 & $<290$ & 410 & 370 & 409 & 500 \\
\hline $\mathrm{Zr} \mathrm{ppm}$ & 149 & $<100$ & 110 & 81 & 148 & 580 \\
\hline Mo ppm & $<6$ & $<6$ & $<4$ & $<3$ & $<6$ & 4.8 \\
\hline Sb ppm & $<0.09$ & $<0.08$ & $<0.1$ & $<0.07$ & $<0.09$ & 0.24 \\
\hline Cs ppm & 0.35 & $<0.2$ & $<0.2$ & $<0.2$ & $<0.2$ & 0.36 \\
\hline Ва ppm & 116 & $<90$ & 117 & 116 & 100 & 518 \\
\hline La ppm & 11.6 & 5.90 & 11.5 & 11.8 & 10.4 & 63.6 \\
\hline Ce ppm & 28.1 & 14.7 & 27.6 & 28.6 & 26.0 & 142.9 \\
\hline Nd ppm & 16.3 & 8.2 & 15.4 & 16.1 & 14.1 & 82.3 \\
\hline Sm ppm & 4.35 & 2.32 & 4.42 & 4.41 & 4.01 & 20.7 \\
\hline Eu ppm & 1.35 & 0.769 & 1.41 & 1.39 & 1.35 & 5.59 \\
\hline $\mathrm{Tb} \mathrm{ppm}$ & 0.631 & 0.368 & 0.658 & 0.670 & 0.585 & 2.79 \\
\hline $\mathrm{Yb} \mathrm{ppm}$ & 1.37 & 0.84 & 1.56 & 1.45 & 1.29 & 6.18 \\
\hline Lu ppm & 0.187 & 0.115 & 0.193 & 0.191 & 0.184 & 0.813 \\
\hline Hf ppm & 2.88 & 1.44 & 2.95 & 2.88 & 2.63 & 14.37 \\
\hline Та ppm & 1.03 & 0.47 & 0.95 & 1.00 & 0.88 & 4.16 \\
\hline $\mathrm{Au} \mathrm{ppb}$ & $<1$ & $<1$ & $<2$ & $<5$ & $<9$ & $<8$ \\
\hline Th ppm & 0.90 & 0.45 & 0.93 & 0.94 & 0.79 & 5.31 \\
\hline U ppm & 0.24 & $<0.3$ & $<0.4$ & 0.33 & 0.27 & 1.51 \\
\hline $\begin{array}{l}\text { Type of } \\
\text { sample }\end{array}$ & $\begin{array}{c}\text { leopard } \\
\text { rock }\end{array}$ & (V) septum & $\begin{array}{l}\text { foundered } \\
\text { crust }\end{array}$ & $\begin{array}{c}\text { leopard } \\
\text { rock }\end{array}$ & $\begin{array}{l}\text { deepest } \\
\text { core }\end{array}$ & $\begin{array}{l}\text { vein in } \\
\text { vein }\end{array}$ \\
\hline $\begin{array}{l}\text { Contains } \\
\text { glass? }\end{array}$ & yes & yes & yes & yes & yes & no \\
\hline $\begin{array}{l}\text { Quenching } \\
\text { temperature }\end{array}$ & high & high & high & high & high & low \\
\hline
\end{tabular}


Table A6. Instrumental neutron-activation analyses of trace elements from the 1988 Kilauea lki drill core.

[Major-element analyses are in Helz and Taggart (2010). wt \%, weight percent; ppm, parts per million; <, less than]

\begin{tabular}{|c|c|c|c|c|c|c|c|c|}
\hline Field no. & $88-1-198.6$ & $88-1-234.4$ & $88-1-260.0$ & $88-1-268.5$ & $88-1-277.8$ & $88-1-311.6$ & $88-1-371.2$ & $88-1-375.8$ \\
\hline Lab. no. & W-256765 & W-256737 & W-256739 & W-256739 & W-256740 & W-256743 & W-256748 & W-256749 \\
\hline Job no. & CJ13 & CJ12 & CJ12 & CJ12 & CJ12 & CJ12 & CJ12 & CJ12 \\
\hline $\mathrm{MgO}$ wt \% & 22.8 & 23.8 & 25.0 & 23.2 & 23.2 & 18.7 & 18.4 & 18.3 \\
\hline Sc $\mathrm{ppm}$ & 23.3 & 23.2 & 20.8 & 20.9 & 23.3 & 24.6 & 25.3 & 25.0 \\
\hline $\mathrm{Cr}$ ppm & 1660 & 1670 & 1590 & 1337 & 1650 & 1211 & 1263 & 1224 \\
\hline Co ppm & 93.5 & 95.1 & 101.4 & 92.8 & 94.4 & 78.5 & 77.9 & 77.9 \\
\hline $\mathrm{Ni}$ ppm & 1010 & 1020 & 1170 & 1090 & 1010 & 778 & 778 & 764 \\
\hline $\mathrm{Zn} \mathrm{ppm}$ & 88 & 86 & 93 & 93.5 & 86 & 85 & 87 & 93 \\
\hline As ppm & $<0.4$ & $<0.3$ & 0.61 & $<0.4$ & $<0.4$ & $<0.5$ & $<0.5$ & 0.85 \\
\hline Se ppm & $<0.6$ & $<0.7$ & $<0.6$ & $<0.5$ & $<2$ & $<0.6$ & $<0.7$ & $<0.7$ \\
\hline $\mathrm{Rb} \mathrm{ppm}$ & 5.8 & 6.6 & 6 & 9.5 & $<5$ & 9.2 & 8 & 11.4 \\
\hline $\mathrm{Sr} \mathrm{ppm}$ & 255 & 291 & 217 & 254 & 244 & 320 & 310 & 314 \\
\hline $\mathrm{Zr} \mathrm{ppm}$ & $<100$ & $<140$ & 92 & 91 & $<120$ & $<140$ & 103 & $<200$ \\
\hline Mo ppm & $<2$ & $<3$ & $<3$ & $<4$ & $<3$ & $<5$ & $<4$ & $<4$ \\
\hline Sb ppm & 0.17 & $<0.05$ & 0.101 & 0.126 & 0.083 & 0.147 & 0.46 & 0.174 \\
\hline Cs ppm & $<0.1$ & $<0.1$ & $<0.1$ & $<0.1$ & $<0.1$ & $<0.1$ & 0.16 & 0.17 \\
\hline $\mathrm{Ba} \mathrm{ppm}$ & 62 & 58 & 65 & 78 & 54 & 100 & 104 & 95 \\
\hline La ppm & 7.51 & 6.69 & 6.61 & 9.05 & 6.36 & 11.7 & 11.6 & 11.4 \\
\hline Ce ppm & 16.9 & 14.9 & 15.5 & 20.5 & 14.7 & 25.5 & 26.0 & 25.6 \\
\hline $\mathrm{Nd} \mathrm{ppm}$ & 10.1 & 9.7 & 8.7 & 11.6 & 8.8 & 16.7 & 15.9 & 15.8 \\
\hline Sm ppm & 2.96 & 2.65 & 2.62 & 3.43 & 2.58 & 4.33 & 4.44 & 4.34 \\
\hline Eu ppm & 0.973 & 0.912 & 0.876 & 1.11 & 0.891 & 1.41 & 1.39 & 1.37 \\
\hline $\mathrm{Tb} \mathrm{ppm}$ & 0.443 & 0.397 & 0.378 & 0.48 & 0.378 & 0.661 & 0.661 & 0.636 \\
\hline $\mathrm{Yb} \mathrm{ppm}$ & 1.00 & 0.86 & 0.83 & 1.05 & 0.90 & 1.31 & 1.40 & 1.37 \\
\hline Lu ppm & 0.121 & 0.111 & 0.107 & 0.153 & 0.123 & 0.192 & 0.189 & 0.188 \\
\hline Hf ppm & 1.93 & 1.82 & 1.64 & 2.28 & 1.68 & 2.91 & 2.95 & 2.99 \\
\hline Ta ppm & 0.628 & 0.55 & 0.54 & 0.75 & 0.542 & 0.966 & 0.976 & 0.98 \\
\hline $\mathrm{Au} \mathrm{ppb}$ & $<4$ & $<3$ & $<5$ & $<3$ & $<4$ & $<5$ & $<3$ & $<3$ \\
\hline Th ppm & 0.64 & 0.52 & 0.53 & 0.79 & 0.5 & 1.01 & 0.95 & 0.97 \\
\hline $\mathrm{U}$ ppm & 0.21 & 0.16 & $<0.2$ & 0.28 & $<0.2$ & 0.3 & 0.3 & 0.36 \\
\hline $\begin{array}{l}\text { Type of } \\
\text { sample }\end{array}$ & (V) & (V) & (V) & $\begin{array}{l}\text { speckled } \\
\text { rock body }\end{array}$ & (V) & (VII) & deepest core & \\
\hline $\begin{array}{l}\text { Contains } \\
\text { glass? }\end{array}$ & no & no & yes & yes & yes & no & no & no \\
\hline $\begin{array}{l}\text { Quenching } \\
\text { temperature }\end{array}$ & low & medium & high & high & high & high & medium & medium \\
\hline
\end{tabular}


Table A6. Instrumental neutron-activation analyses of trace elements from the 1988 Kilauea Iki drill core.Continued

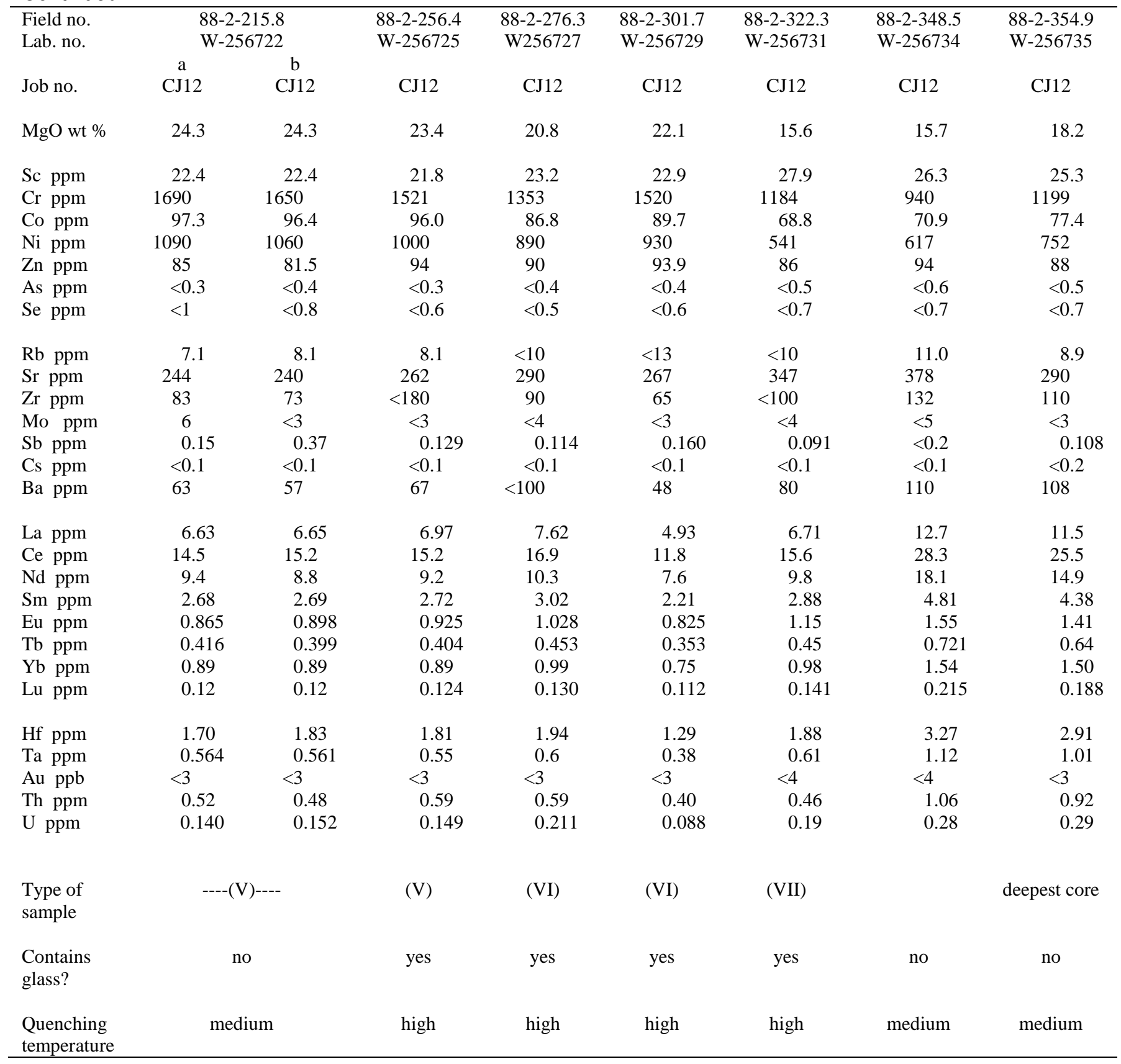


Table B1. Energy-dispersive X-ray fluorescence analyses of trace elements in samples from the 1959 Kilauea Iki eruption.

[Major-element analyses are as in table A1. Mixing fractions are from Wright (1973). wt \%, weight percent; ppm, parts per million; ${ }^{\circ} \mathrm{C}$, degrees Celsius; $<$, less than]

\begin{tabular}{|c|c|c|c|c|c|c|}
\hline Field no. & Iki-1 & Iki-58 & Iki-22 & Iki-3 & Iki-44 & Iki-38 \\
\hline Lab. no. & $\mathrm{S}-2$ & S-1 & S-5 & D-571089 & S-7 & S-25 \\
\hline Job no. & CH91 & CH91 & CH91 & CH91 & CH91 & CH91 \\
\hline MgO (wt\%) & 7.23 & 8.08 & 19.52 & 17.2 & 13.67 & 8.85 \\
\hline $\mathrm{Nb}$ ppm & 23 & 23 & 15 & 21 & 21 & 19 \\
\hline $\mathrm{Rb}$ ppm & 16 & 12 & $<10$ & 16 & 14 & 14 \\
\hline Sr ppm & 385 & 365 & 275 & 300 & 335 & 370 \\
\hline $\mathrm{Zr}$ ppm & 184 & 176 & 130 & 142 & 158 & 178 \\
\hline Y ppm & 28 & 31 & 23 & 32 & 27 & 32 \\
\hline $\mathrm{Cu} \mathrm{ppm}$ & 122 & 124 & 120 & 102 & 114 & 144 \\
\hline $\mathrm{Ni}$ ppm & 112 & 130 & 790 & 610 & 480 & 240 \\
\hline Zn ppm & 100 & 102 & 104 & 96 & 114 & 112 \\
\hline $\begin{array}{l}\text { Phase of } \\
\text { eruption }\end{array}$ & 1 & 1 & 1 & 1 & 1 & 17 \\
\hline $\begin{array}{l}\text { Fraction } \\
\mathrm{S}-1 /(\mathrm{S}-1+\mathrm{S}+2)\end{array}$ & 0 & 1 & 0.68 & 0.75 & 0.057 & 0 \\
\hline $\begin{array}{l}\text { Quenching } \\
\text { temperature }\left({ }^{\circ} \mathrm{C}\right)\end{array}$ & 1142 & 1144 & 1217 & 1213 & 1187 & --- \\
\hline
\end{tabular}


Table B2. Energy-dispersive X-ray fluorescence analyses of trace elements for samples from 1967 Kilauea lki drill core.

[wt \%, weight percent; ppm, parts per million]

\begin{tabular}{|c|c|c|c|c|c|c|c|c|c|c|c|c|c|}
\hline $\begin{array}{l}\text { Field no. } \\
\text { Lab. no. } \\
\text { Job no. }\end{array}$ & $\begin{array}{c}\text { 67-1-89.0 } \\
\text { D-102046 } \\
\text { CH90 }\end{array}$ & $\begin{array}{c}\text { 67-2-17.0 } \\
\text { W-214299 } \\
\text { CH90 }\end{array}$ & $\begin{array}{c}\text { 67-2-59.8 } \\
\text { W-214301 } \\
\text { CH90 }\end{array}$ & $\begin{array}{c}\text { 67-2-79.9 } \\
\text { W-214302 } \\
\text { CH90 }\end{array}$ & $\begin{array}{c}\text { 67-2-85.7 } \\
\text { D-102048 } \\
\text { CH90 }\end{array}$ & $\begin{array}{c}\text { 67-2-89.5 } \\
\text { D-102050 } \\
\text { CH90 }\end{array}$ & $\begin{array}{c}\text { 67-2-94.6 } \\
\text { D-103993 } \\
\text { CH90 }\end{array}$ & $\begin{array}{c}\text { 67-3-6.8 } \\
\text { W-214121 } \\
\text { CH91 }\end{array}$ & $\begin{array}{c}\text { 67-3-27.5 } \\
\text { D-103976 } \\
\text { CH90 }\end{array}$ & $\begin{array}{c}\text { 67-3-39.0 } \\
\text { D-103977 } \\
\text { CH91 }\end{array}$ & $\begin{array}{c}\text { 67-3-47.8 } \\
\text { D-103978 } \\
\text { CH91 }\end{array}$ & $\begin{array}{c}\text { 67-3-58.0 } \\
\text { D-103979 } \\
\text { CH90 }\end{array}$ & $\begin{array}{c}\text { 67-3-87.0 } \\
\text { D-102054 } \\
\text { CH90 }\end{array}$ \\
\hline MgO (wt \%) & 4.83 & 18.26 & 16.53 & 22.34 & 2.60 & 13.07 & 15.91 & 25.83 & 12.01 & 10.73 & 13.10 & 8.91 & 5.44 \\
\hline $\mathrm{Nb}$ ppm & 37 & 15 & 18 & 16 & 56 & 23 & 16 & 14 & 18 & 21 & 19 & 23 & 33 \\
\hline $\mathrm{Rb} \mathrm{ppm}$ & 21 & 12 & 12 & 15 & 46 & 15 & 11 & 10 & 11 & 11 & 16 & 17 & 21 \\
\hline Sr ppm & 405 & 295 & 310 & 255 & 430 & 335 & 305 & 215 & 345 & 365 & 345 & 410 & 415 \\
\hline Zr ppm & 305 & 124 & 134 & 104 & 580 & 172 & 122 & 97 & 156 & 172 & 164 & 192 & 285 \\
\hline Y ppm & 43 & 24 & 26 & 25 & 70 & 31 & 24 & 22 & 27 & 30 & 30 & 33 & 40 \\
\hline $\mathrm{Cu} \mathrm{ppm}$ & 215 & 81 & 102 & 78 & 450 & 140 & 93 & 60 & 86 & 104 & 99 & 100 & 215 \\
\hline $\mathrm{Ni}$ ppm & 78 & 710 & 600 & 920 & 22 & 440 & 495 & 1200 & 320 & 265 & 400 & 210 & 79 \\
\hline Zn ppm & 128 & 95 & 94 & 97 & 152 & 110 & 87 & 90 & 92 & 86 & 90 & 82 & 126 \\
\hline $\begin{array}{l}\text { Type of } \\
\text { sample }\end{array}$ & $\begin{array}{l}\text { glass } \\
\text { in bit }\end{array}$ & (I) & $\begin{array}{l}\text { foundered } \\
\text { crust }\end{array}$ & $\begin{array}{l}\text { foundered } \\
\text { crust }\end{array}$ & ooze & $\begin{array}{l}\text { leopard } \\
\text { rock }\end{array}$ & $\begin{array}{l}\text { foundered } \\
\text { crust }\end{array}$ & (I) & (I) & (I) & (II) & (II) & $\begin{array}{l}\text { glass } \\
\text { in bit }\end{array}$ \\
\hline $\begin{array}{l}\text { Contains } \\
\text { glass? }\end{array}$ & yes & no & yes & yes & yes & yes & yes & no & no & no & no & no & yes \\
\hline $\begin{array}{l}\text { Quenching } \\
\text { temperature }\end{array}$ & high & low & medium & high & high & high & high & low & low & low & medium & medium & high \\
\hline
\end{tabular}


Table B3. Energy-dispersive X-ray fluorescence analyses of trace elements for samples from 1975 Kilauea lki drill core.

[wt \%, weight percent; ppm, parts per million]

\begin{tabular}{|c|c|c|c|c|c|c|c|c|c|c|c|c|c|}
\hline Field no. & $75-1-60.9$ & $75-1-75.2$ & $75-1-85.5$ & $75-1-95.0$ & $75-1-110$ & $75-1-114.9$ & $75-1-121.5$ & 75-1-133.4 & 75-1-141.9 & $75-3-100.9$ & $75-3-106.0$ & $75-3-123.2$ & $75-3-144.4$ \\
\hline Lab. No. & D-103844 & D-103846 & $\begin{array}{c}\text { D- } \\
103848\end{array}$ & D-103850 & D-103852 & D-103853 & D-103855 & D-103856 & D-103859 & D-103873 & D-103874 & D-103839 & D-103877 \\
\hline Job no. & CH91 & CH91 & CH91 & CH90 & CH90 & CH90 & CH91 & CH91 & CH90 & CH90 & CH90 & CH90 & CH90 \\
\hline MgO (wt \%) & 10.52 & 5.77 & 8.33 & 9.64 & 8.27 & 5.26 & 7.77 & 10.65 & 11.62 & 9.12 & 7.98 & 8.71 & 16.20 \\
\hline $\mathrm{Nb}$ ppm & 21 & 25 & 20 & 21 & 22 & 34 & 22 & 24 & 21 & 20 & 23 & 20 & 16 \\
\hline $\mathrm{Rb} \mathrm{ppm}$ & 16 & 18 & 11 & 12 & 16 & 26 & 19 & 14 & 11 & 19 & 17 & 16 & 14 \\
\hline Sr ppm & 385 & 450 & 410 & 400 & 410 & 465 & 430 & 375 & 350 & 375 & 400 & 390 & 305 \\
\hline $\mathrm{Zr} \mathrm{ppm}$ & 182 & 240 & 184 & 170 & 190 & 295 & 198 & 178 & 164 & 180 & 186 & 172 & 136 \\
\hline Y ppm & 32 & 38 & 32 & 31 & 32 & 47 & 37 & 32 & 29 & 32 & 32 & 30 & 28 \\
\hline $\mathrm{Cu} \mathrm{ppm}$ & 106 & 168 & 118 & 110 & 122 & 190 & 138 & 104 & 114 & 92 & 124 & 114 & 102 \\
\hline $\mathrm{Ni}$ ppm & 260 & 72 & 180 & 230 & 180 & 57 & 146 & 280 & 330 & 158 & 110 & 154 & 540 \\
\hline $\mathrm{Zn} \mathrm{ppm}$ & 85 & 89 & 77 & 79 & 79 & 91 & 73 & 85 & 87 & 81 & 80 & 78 & 90 \\
\hline $\begin{array}{l}\text { Type of } \\
\text { sample }\end{array}$ & (II) & $\begin{array}{l}\text { segregation } \\
\text { vein }\end{array}$ & (II) & (II) & (II) & $\begin{array}{l}\text { segregation } \\
\text { vein }\end{array}$ & (II) & (III) & (III) & & & & \\
\hline $\begin{array}{l}\text { Contains } \\
\text { glass? }\end{array}$ & no & no & no & no & no & no & no & yes & yes & no & no & no & yes \\
\hline $\begin{array}{l}\text { Quenching } \\
\text { temperature }\end{array}$ & low & low & low & low & medium & medium & medium & high & high & low & low & medium & high \\
\hline
\end{tabular}


Table B4. Energy-dispersive X-ray fluorescence analyses of trace elements for samples from 1979 Kilauea lki core.

[wt \%, weight percent; ppm, parts per million; <, less than]

\begin{tabular}{|c|c|c|c|c|c|c|c|c|c|c|c|}
\hline Field no. & 79-1R1-167.8 & 79-1R1-170.9 & 79-3-145.1 & 79-3-150.4 & 79-3-158.0 & 79-3-160.3 & 79-3-172.8 & 79-3R2-168.0 & $79-5-160.0$ & 79-5-163 & $79-5-180.5$ \\
\hline Lab. no. & W-235378 & W-235380 & W-210495 & W-210496 & W-214317 & W-210497 & W-210500 & W-235391 & W-214304 & ---- & W-214305 \\
\hline Job no. & CH90 & CH90 & CH91 & CH91 & CH91 & CH90 & CH91 & CH90 & CH90 & CH90 & CH90 \\
\hline MgO (wt \%) & 3.42 & 3.48 & 26.16 & 13.51 & 4.5 & 16.05 & 18.71 & 5.07 & 22.08 & 2.57 & 20.7 \\
\hline $\mathrm{Nb}$ ppm & 48 & 51 & 13 & 17 & 37 & 16 & 15 & 38 & 13 & 61 & 15 \\
\hline $\mathrm{Rb} \mathrm{ppm}$ & 34 & 35 & $<10$ & 14 & 27 & $<10$ & $<10$ & 21 & 11 & 64 & $<10$ \\
\hline Sr ppm & 430 & 430 & 194 & 335 & 440 & 310 & 265 & 410 & 240 & 360 & 255 \\
\hline $\mathrm{Zr} \mathrm{ppm}$ & 480 & 475 & 83 & 144 & 375 & 136 & 118 & 315 & 96 & 680 & 106 \\
\hline Y ppm & 63 & 61 & 19 & 29 & 51 & 25 & 24 & 45 & 21 & 79 & 23 \\
\hline $\mathrm{Cu}$ ppm & 210 & 365 & 58 & 102 & 196 & 92 & 93 & 245 & 76 & 640 & 81 \\
\hline $\mathrm{Ni}$ ppm & 35 & 27 & 1100 & 405 & 61 & 570 & 700 & 73 & 850 & 31 & 790 \\
\hline Zn ppm & 134 & 134 & 112 & 88 & 100 & 95 & 97 & 124 & 96 & 58 & 93 \\
\hline $\begin{array}{l}\text { Type of } \\
\text { sample }\end{array}$ & Ooze & ooze & vorb & (III) & $\begin{array}{l}\text { segregation } \\
\text { vein }\end{array}$ & (IV) & (IV) & ooze & & thin vein & \\
\hline $\begin{array}{l}\text { Contains } \\
\text { glass? }\end{array}$ & Yes & yes & trace? & no & yes & yes & yes & yes? & no & yes & trace \\
\hline $\begin{array}{l}\text { Quenching } \\
\text { temperature }\end{array}$ & High & high & medium & medium & high & high & high & medium & medium & high & high \\
\hline
\end{tabular}


Table B4. Energy-dispersive X-ray fluorescence analyses of trace elements for samples from 1979 Kilauea Iki core.-Continued

\begin{tabular}{|c|c|c|c|c|c|}
\hline Field no & $79-5-200.0$ & $79-5-240.0$ & $79-5-260.0$ & $79-5-300.5$ & $79-5-313.5$ \\
\hline Lab no. & W-214306 & W-214308 & W-214309 & W-214311 & W-214313 \\
\hline Job no. & СH90 & СH90 & CH91 & CH90 & СH90 \\
\hline MgO (wt \%) & 21.30 & 20.35 & 18.84 & 16.61 & 9.51 \\
\hline Nb ppm & 13 & 13 & 18 & 16 & 20 \\
\hline $\mathrm{Rb} p p m$ & $<10$ & 11 & 14 & 12 & 15 \\
\hline Sr ppm & 255 & 270 & 290 & 305 & 365 \\
\hline Zr ppm & 106 & 104 & 124 & 136 & 172 \\
\hline Y ppm & 24 & 24 & 28 & 26 & 31 \\
\hline $\mathrm{Cu}$ ppm & 90 & 94 & 91 & 96 & 108 \\
\hline Ni ppm & 800 & 770 & 680 & 610 & 210 \\
\hline Zn ppm & 104 & 96 & 87 & 95 & 89 \\
\hline $\begin{array}{l}\text { Type of } \\
\text { sample }\end{array}$ & & & chill & chill & chill \\
\hline $\begin{array}{l}\text { Contains } \\
\text { glass? }\end{array}$ & trace & no & no & no & no \\
\hline $\begin{array}{l}\text { Quenching } \\
\text { temperature }\end{array}$ & high & medium & medium & medium & medium \\
\hline
\end{tabular}


Table B5. Energy-dispersive X-ray fluorescence analyses of trace elements from 1981 Kilauea lki drill core.

[wt \%, weight percent; ppm, parts per million; <, less than]

\begin{tabular}{|c|c|c|c|c|c|c|c|c|c|c|c|}
\hline Field no. & $81-1-117.8$ & $81-1-119.2$ & $81-1-120.3$ & $81-1-169.9$ & 81-1-190.1 & $81-1-200.4$ & $81-1-210.0$ & $81-1-230.6$ & 81-1-239.9 & $81-1-250.0$ & $81-1-260.0$ \\
\hline Lab. no. & W-239453 & W-239454 & W-239455 & W-214102 & W-210104 & W-214105 & W-214106 & W-214108 & W-214109 & W-214110 & W-214111 \\
\hline Job no. & CH90 & CH91 & CH91 & CH91 & CH91 & CH90 & CH90 & CH91 & CH90 & CH90 & CH91 \\
\hline MgO (wt \%) & 4.86 & 6.74 & 6.95 & 26.87 & 21.91 & 25.96 & 24.53 & 24.83 & 26.55 & 25.43 & 22.77 \\
\hline Nb ppm & 36 & 21 & 24 & 14 & 15 & 13 & 12 & 12 & 10 & 11 & 14 \\
\hline $\mathrm{Rb} \mathrm{ppm}$ & 25 & 14 & 16 & 11 & 13 & $<10$ & $<10$ & 11 & $<10$ & 11 & $<10$ \\
\hline Sr ppm & 450 & 440 & 440 & 180 & 240 & 192 & 200 & 205 & 186 & 205 & 230 \\
\hline $\mathrm{Zr} \mathrm{ppm}$ & 305 & 205 & 205 & 97 & 108 & 98 & 80 & 81 & 73 & 83 & 85 \\
\hline Y ppm & 45 & 33 & 36 & 22 & 24 & 20 & 18 & 19 & 17 & 20 & 18 \\
\hline $\mathrm{Cu} \mathrm{ppm}$ & 220 & 132 & 138 & 70 & 88 & 88 & 63 & 70 & 66 & 67 & 71 \\
\hline $\mathrm{Ni} \mathrm{ppm}$ & 63 & 122 & 128 & 1100 & 860 & 1100 & 1000 & 1000 & 1100 & 1050 & 910 \\
\hline Zn ppm & 92 & 72 & 77 & 116 & 96 & 116 & 102 & 99 & 106 & 104 & 97 \\
\hline $\begin{array}{l}\text { Type of } \\
\text { sample }\end{array}$ & (II) & (II) & (II) & vorb & (V) & ogb & (V) & $(\mathrm{V})$ & (V) & (V) & (V) \\
\hline $\begin{array}{l}\text { Contains } \\
\text { glass? }\end{array}$ & no & no & no & yes & yes & yes & yes & yes & yes & yes & yes \\
\hline $\begin{array}{l}\text { Quenching } \\
\text { temperature }\end{array}$ & low & low & low & high & high & high & high & high & high & high & high \\
\hline
\end{tabular}


Table B5. Energy-dispersive X-ray fluorescence analyses of trace elements from 1981 Kilauea Iki drill core.-Continued

\begin{tabular}{|c|c|c|c|c|c|c|c|c|c|}
\hline Field no. & $81-1-270.2$ & $81-1-273.6$ & $81-1-280.0$ & 81-1-281.6 & $81-1-289.3$ & $81-1-297.9$ & $81-1-300.2$ & $81-1-306.7$ & $81-2-88.6$ \\
\hline Lab no. & W-214112 & W-214113 & W-214114 & W-214115 & W-214116 & W-214 118 & W-214119 & W-214120 & W-232725 \\
\hline Job no. & СH90 & CH91 & CH91 & CH91 & CH90 & СH90 & CH91 & CH91 & CH91 \\
\hline MgO (wt \%) & 18.79 & 11.95 & 26.15 & 18.74 & 25.58 & 15.64 & 18.15 & 17.47 & 2.37 \\
\hline $\mathrm{Nb}$ ppm & 10 & 14 & 10 & 17 & 11 & 16 & 18 & 14 & 55 \\
\hline $\mathrm{Rb} \mathrm{ppm}$ & $<10$ & $<10$ & $<10$ & 12 & $<10$ & 10 & 15 & $<10$ & 43 \\
\hline Sr ppm & 260 & 350 & 200 & 275 & 205 & 310 & 285 & 295 & 430 \\
\hline $\mathrm{Zr} \mathrm{ppm}$ & 76 & 108 & 80 & 132 & 75 & 132 & 132 & 118 & 590 \\
\hline Y ppm & 18 & 23 & 19 & 24 & 18 & 23 & 23 & 23 & 70 \\
\hline $\mathrm{Cu} \mathrm{ppm}$ & 50 & 70 & 67 & 102 & 64 & 102 & 98 & 92 & 345 \\
\hline $\mathrm{Ni}$ ppm & 620 & 290 & 1100 & 710 & 1100 & 530 & 650 & 630 & $<10$ \\
\hline Zn ppm & 88 & 75 & 97 & 98 & 106 & 93 & 102 & 92 & 108 \\
\hline $\begin{array}{l}\text { Type of } \\
\text { sample }\end{array}$ & (VI) & (VI) & (VI) & $\begin{array}{l}\text { leopard } \\
\text { rock }\end{array}$ & $\begin{array}{c}(\mathrm{V}) \\
\text { septum }\end{array}$ & $\begin{array}{l}\text { foundered } \\
\text { crust }\end{array}$ & $\begin{array}{c}\text { leopard } \\
\text { rock }\end{array}$ & $\begin{array}{l}\text { deepest } \\
\text { core }\end{array}$ & $\begin{array}{l}\text { vein in } \\
\text { vein }\end{array}$ \\
\hline $\begin{array}{l}\text { Contains } \\
\text { glass? }\end{array}$ & yes & yes & yes & yes & yes & yes & yes & yes & no \\
\hline $\begin{array}{l}\text { Quenching } \\
\text { temperature }\end{array}$ & high & high & high & high & high & high & high & high & low \\
\hline
\end{tabular}

